\title{
Calcium deficiency-induced and TRP channel-regulated IGF1R-PI3K-Akt signaling regulates abnormal epithelial cell proliferation
}

\author{
W Dai ${ }^{1}$, Y Bai ${ }^{1}$, L Hebda ${ }^{1}$, X Zhong ${ }^{1,2}$, J Liu' ${ }^{1}$, K Kao ${ }^{1}$ and C Duan ${ }^{\star, 1}$
}

Calcium deficiency causes abnormal colonic growth and increases colon cancer risk with poorly understood mechanisms. Here we elucidate a novel signaling mechanism underlying the $\mathrm{Ca}^{2+}$ deficiency-induced epithelial proliferation using a unique animal model. The zebrafish larval yolk sac skin contains a group of $\mathrm{Ca}^{2+}$-transporting epithelial cells known as ionocytes. Their number and density increases dramatically when acclimated to low $\left.\mathrm{Ca}^{2+}\right]$ environments. BrdU pulse-labeling experiments suggest that low $\left[\mathrm{Ca}^{2+}\right]$ stimulates pre-existing ionocytes to re-enter the cell cycle. Low $\left[\mathrm{Ca}^{2+}\right]$ treatment results in a robust and sustained activation of IGF1R-PI3K-Akt signaling in these cells exclusively. These ionocytes specifically express Igfbp5a, a high-affinity and specific binding protein for insulin-like growth factors (IGFs) and the $\mathrm{Ca}^{2+}$-selective channel Trpv5/6. Inhibition or knockdown of Igfbp5a, IGF1 receptor, PI3K, and Akt attenuates low $\left[\mathrm{Ca}^{2+}\right.$ ]-induced ionocyte proliferation. The role of Trpv5/6 was investigated using a genetic mutant, targeted knockdown, and pharmacological inhibition. Loss-of-Trpv5/6 function or expression results in elevated pAkt levels and increased ionocyte proliferation under normal $\left[\mathrm{Ca}^{2+}\right]$. These increases are eliminated in the presence of an IGF1R inhibitor, suggesting that Trpv5/6 represses IGF1R-PI3K-Akt signaling under normal $\left[\mathrm{Ca}^{2+}\right]$. Intriguingly, blockade of Trpv5/6 activity inhibits the low $\left[\mathrm{Ca}^{2+}\right]$-induced activation of Akt. Mechanistic analyses reveal that the low $\left[\mathrm{Ca}^{2+}\right.$-induced IGF signaling is mediated through Trpv5/6-associated membrane depolarization. Low extracellular $\left[\mathrm{Ca}^{2+}\right.$ ] results in a similar amplification of IGF-induced PI3K-PDK1-Akt signaling in human colon cancer cells in a TRPV6-dependent manner. These results uncover a novel and evolutionarily conserved signaling mechanism that contributes to the abnormal epithelial proliferation associated with $\mathrm{Ca}^{2+}$ deficiency.

Cell Death and Differentiation (2014) 21, 568-581; doi:10.1038/cdd.2013.177; published online 13 December 2013

Colon cancer is a leading cause of cancer deaths worldwide. Clinical studies have shown that there is an inverse association between dietary intake of $\mathrm{Ca}^{2+}$ and the risk of colorectal cancer. ${ }^{1-3}$ In fact, low dietary $\mathrm{Ca}^{2+}$ has been proposed as a risk factor for enhanced colonic epithelial growth and colon cancer. ${ }^{4,5}$ Dietary $\mathrm{Ca}^{2+}$ deficiency results in abnormal epithelial cell proliferation in the intestine, and dietary $\mathrm{Ca}^{2+}$ supplementation reduces these abnormalities. ${ }^{4}$ Although $\mathrm{Ca}^{2+}$ deficiency has been known to increase colon epithelial growth, the cellular basis and the regulatory mechanisms are poorly understood.

In this study, we used a unique animal model, the zebrafish embryo/larval yolk sac skin, to elucidate the mechanisms underlying $\mathrm{Ca}^{2+}$ deficiency-induced abnormal epithelial growth. Fish live in aquatic habitats and must obtain $\mathrm{Ca}^{2+}$ from food and surrounding water. A group of mitochondriarich epithelial cells known as $\mathrm{Na}^{+}-\mathrm{K}^{+}$-ATPase-rich (NaR) cells are responsible for $\mathrm{Ca}^{2+}$ uptake from the surrounding environment. ${ }^{6}$ In the adult stage, these cells are located in the gill filaments and the intestine. In the embryonic and larval stages before the appearance of gills, however, NaR cells are located on the surface of the yolk sac skin. ${ }^{6}$ These specialized cells contain all the molecular factors for transcellular $\mathrm{Ca}^{2+}$ transport, including Trpv5/6 (formerly known as epithelial $\mathrm{Ca}^{2+}$ channel). ${ }^{6,7}$ Zebrafish trpv5/6 is the zebrafish ortholog of human TRPV5 and TRPV6. ${ }^{8}$ TRPV 5 and TRPV 6 are the only known $\mathrm{Ca}^{2+}$-selective channels in the transient receptor potential (TRP) channel family, and they have key roles in the transcellular $\mathrm{Ca}^{2+}$ transport. ${ }^{9}$ While TRPV5 is mainly expressed in the mammalian kidneys, TRPV6 is expressed in the intestine. ${ }^{10}$ In contrast to the presence of a separate TRPV5 gene and a TRPV6 gene in humans and mammals, zebrafish have a single trpv5/6 gene, thus eliminating concerns for possible functional redundancy and compensatory mechanisms seen in mammals. ${ }^{8,11}$ In the adult stage, zebrafish trpv5/6 mRNA is expressed in the gills and intestine. ${ }^{11}$ In the embryonic and larval stages, trpv5/6 is specifically expressed in NaR cells located on the surface of the yolk sac skin. ${ }^{6}$ These unique anatomical and molecular features make the zebrafish yolk sac skin an excellent in vivo

\footnotetext{
${ }^{1}$ Department of Molecular, Cellular and Developmental Biology, University of Michigan, Ann Arbor, Ml 48109, USA and ${ }^{2}$ Hubei Key Laboratory of Genetic Regulation and Integrative Biology, College of Life Sciences, Central China Normal University, Wuhan 430079, China

*Corresponding author: C Duan, Department of Molecular, Cellular and Developmental Biology, University of Michigan, 830 North University Avenue, Nat Sci Building, Rm 3065B, Ann Arbor, Ml 48109, USA. Tel: + 734763 4710; Fax: + 734647 0884; E-mail: cduan@umich.edu

Keywords: transient receptor potential vanilloid; insulin-like growth factor binding protein 5; zebrafish; colon cancer cell; epithelial growth; membrane depolarization Abbreviations: IGF, insulin-like growth factors; IGFBP, insulin-like growth factor binding protein; IGF1R, insulin-like growth factor 1 receptor; $\mathrm{NaR}$ cell, $\mathrm{Na}^{+}-\mathrm{K}^{+}$. ATPase-rich cell; TRPV, transient receptor potential vanilloid; CaM, calmodulin; hpf, hour post fertilization; $\mathrm{HR}$ cell, $\mathrm{H}^{+}$-ATPase-rich cell; $\mathrm{NCC}^{-}$cell, $\mathrm{Na}^{+} / \mathrm{Cl}^{-}$ cotransporter cell; pAkt, phoshpo-Akt; pErk, phosphor-Erk; CaSR, $\mathrm{Ca}^{2+}$-sensing receptor

Received 17.4.13; revised 25.9.13; accepted 16.10.13; Edited by B Zhivotovsky; published online 13.12.13
} 
model to study the function and regulation of $\mathrm{Ca}^{2+}$. transporting epithelium. As in the case of human colonic epithelium, a reduction in water $\mathrm{Ca}^{2+}$ concentration $\left(\left[\mathrm{Ca}^{2+}\right]\right)$ increases $\mathrm{NaR}$ cell number on the yolk sac skin in zebrafish embryos and larvae. ${ }^{11}$ In fact, acclimation to low $\left[\mathrm{Ca}^{2+}\right]$ has been shown to increase ionocyte number and/or density in the adult gills in many teleost species for more than two decades, ${ }^{12,13}$ suggesting an evolutionarily conserved regulatory mechanism at work.

In our recent efforts to elucidate the developmental role of the insulin-like growth factor (IGF) signaling system in zebrafish, we have made the serendipitous finding that igfbp5a, a gene encoding a high-affinity IGF-binding protein (Igfbp), is highly expressed in a group of cells scattered over the larval yolk sac skin. ${ }^{14}$ Its expression pattern resembles that of trpv5/6, which is specifically expressed in NaR cells. ${ }^{11}$ IGFs are evolutionarily conserved peptides that have key roles in regulating cell proliferation, growth, differentiation, and survival. ${ }^{15}$ The biological actions of IGFs are mediated through the IGF1 receptor (IGF1R). Signaling through the IGF1R is transduced primarily by the PI3K-Akt and the MEKErk cascades in zebrafish cells. ${ }^{16}$ In extracellular fluids, IGFs are present in complexes with a family of high-affinity IGFBPs. These IGFBPs bind to IGFs with equal or even greater affinities than do the IGF1Rs and modulate the distribution, stability, and biological activities of IGFs. ${ }^{15}$

The objective of this study was to test the hypothesis that low $\left[\mathrm{Ca}^{2+}\right.$ ] activates IGF signaling in NaR cells via Trpv5/6 and Igfbp5a, leading to increased $\mathrm{NaR}$ cell proliferation in the larval skin. Our results suggest that $\mathrm{Ca}^{2+}$ deficiency activates IGF signaling in $\mathrm{NaR}$ cells exclusively and stimulates the preexisting $\mathrm{NaR}$ cells to re-enter the cell cycle. Inhibition or knockdown of Igfbp5a, IGF1R, PI3K, and Akt inhibits $\mathrm{Ca}^{2+}$ deficiency-induced abnormal proliferation. We provide several lines of evidence suggesting that while Trpv5/6 represses IGF signaling under normal $\left[\mathrm{Ca}^{2+}\right]$ conditions, its altered activity under low $\left[\mathrm{Ca}^{2+}\right.$ ] conditions activates IGF1R-PI3KAkt. We further show that reducing extracellular $\left[\mathrm{Ca}^{2+}\right]$ results in a similar amplification of IGF-induced PI3K-PDK1Akt signaling in cultured colon cancer cells. This amplification is mediated by TRPV6.

\section{Results}

Low $\left[\mathrm{Ca}^{2+}\right]$ acclimation increases $\mathrm{NaR}$ cell number and density by reactivating a mitotic program in pre-existing NaR cells. To determine the effect of $\left[\mathrm{Ca}^{2+}\right]$ on $\mathrm{NaR}$ cell growth, 72-hpf (hour post fertilization) zebrafish larvae were transferred to low $\left[\mathrm{Ca}^{2+}\right](0.001 \mathrm{mM})$ and raised until $120 \mathrm{hpf}$. Acclimation to low $\left[\mathrm{Ca}^{2+}\right.$ ] water resulted in a robust increase in the density of $\mathrm{NaR}$ cells on the yolk sac skin (Figures $1 \mathrm{a}$ and $\mathrm{b}$ ). This effect was specific to low $\left[\mathrm{Ca}^{2+}\right]$ because acclimation to low $\left[\mathrm{Na}^{+}\right]$or low $\left[\mathrm{Cl}^{-}\right]$water had no such effect (Figures 1a and b). Zebrafish larval yolk sac skin contains other types of ionocytes, including $\mathrm{H}^{+}$-ATPase-rich (HR) cells and $\mathrm{Na}^{+} / \mathrm{Cl}^{-}$cotransporter (NCC) cells. HR cells are involved in $\mathrm{Na}^{+}$uptake/acid secretion, and NCC cells are important for $\mathrm{Cl}^{-}$uptake. ${ }^{6} \mathrm{HR}$ cells and NCC cells can be labeled by atp6v1al mRNA and slc12a10.2 mRNA, respectively. ${ }^{17,18}$ Acclimation to low $\left[\mathrm{Ca}^{2+}\right]$, low $\left[\mathrm{Na}^{+}\right]$, or low $\left[\mathrm{Cl}^{-}\right]$did not change HR cell number (Figures 1a and b). A modest increase was seen in NCC cell number in the low $\left[\mathrm{Ca}^{2+}\right]$ group, whereas low $\left[\mathrm{Na}^{+}\right]$or low $\left[\mathrm{Cl}^{-}\right]$had no effect (Figures $1 \mathrm{a}$ and $\mathrm{b}$ ).

To determine whether the low $\left[\mathrm{Ca}^{2+}\right]$-induced increase in $\mathrm{NaR}$ cells is due to elevated cell proliferation, BrdU-labeling experiments were carried out. Compared with the normal $\left[\mathrm{Ca}^{2+}\right]$ group, there was a robust increase in BrdU-positive cells in the low $\left[\mathrm{Ca}^{2+}\right]$ group (Figure 1c). Next, mitotic cells were pulse-labeled. While only $3 \%$ of $\mathrm{NaR}$ cells were labeled by BrdU in the normal $\left[\mathrm{Ca}^{2+}\right]$ group $(n=30), 20 \%$ of NaR cells were BrdU-positive in the low $\left[\mathrm{Ca}^{2+}\right]$ group (Figure 1d) $(n=161)$. These results suggest that low $\left[\mathrm{Ca}^{2+}\right]$ treatment increases $\mathrm{NaR}$ cell number by stimulating the proliferation of pre-existing NaR cells.

The igfbp5a mRNA is specifically expressed in NaR cells and its levels are correlated with $\mathrm{NaR}$ cell number. As mentioned earlier, igfbp5a mRNA is expressed in a group of cells on the yolk sac skin resembling NaR cells. ${ }^{14}$ When subjected to low $\left[\mathrm{Ca}^{2+}\right]$ treatment, there was a similar degree of increase in the number of trpv5/6 mRNAexpressing NaR cells and igfbp5a mRNA-expressing cells (Figures $2 \mathrm{a}$ and b). Double-label in situ hybridization analysis revealed that igfbp5a mRNA was detected in $99 \%$ of the trpv5/6 mRNA-expressing cells examined $(n=98)$ (Figure 2c). Likewise, trpv5/6 mRNA was detected in $99 \%$ of the igfbp5a mRNA-expressing cells examined $(n=98)$. In comparison, there was no overlap in igfbp5a mRNA and atp6v1al mRNA-expressing HR cells (Figure 2c, $n=99$ ). Further analyses revealed that low $\left[\mathrm{Ca}^{2+}\right]$ treatment increased the $\mathrm{NaR}$ cell number in a concentration-dependent manner (Figure 2d). Reducing water $\left[\mathrm{Ca}^{2+}\right]$ also increased igfbp5a mRNA levels, measured by qRT-PCR (Figure 2e), in a concentration-dependent manner. There is a strong correlation between the igfbp5a mRNA levels and the NaR cell number (Figure 2f). These results suggest that igfbp5a mRNA is co-expressed with trpv5/6 mRNA in NaR cells and that total igfbp5a mRNA levels are a good indicator of $\mathrm{NaR}$ cell number in zebrafish larvae.

Low $\left[\mathrm{Ca}^{2+}\right]$ acclimation activates IGF1R-PI3K-Akt signaling in NaR cells. As igfbp5a mRNA is specifically expressed in NaR cells, and IGFs are potent mitogens for zebrafish cells, ${ }^{16}$ we tested the idea that low $\left[\mathrm{Ca}^{2+}\right]$ stimulates $\mathrm{NaR}$ cell proliferation by activating IGF signaling in these cells. We examined phospho-Akt (pAkt) and phospho-Erk ( $p$ Erk) because commercially available mammalian phospho-IGF1R antibodies did not yield specific signals in zebrafish larvae. While few pAkt-positive cells were detected in the normal $\left[\mathrm{Ca}^{2+}\right]$ group $(0.2 \mathrm{mM})$, reducing $\left[\mathrm{Ca}^{2+}\right]$ to $0.02 \mathrm{mM}$ resulted in a marked increase in pAktpositive cells. There was an even greater increase in the $0.001 \mathrm{mM}\left[\mathrm{Ca}^{2+}\right]$ group (Figure 3a). Addition of Akti-1/2 or MK2206, two selective Akt inhibitors, abolished the pAkt signal (see Supplementary Figure S2), confirming the specificity of the staining. Double-staining experiments indicated that all these pAkt-positive cells are NaR cells because $100 \%$ of them expressed igfbp5a mRNA (Figure 3b, 
a

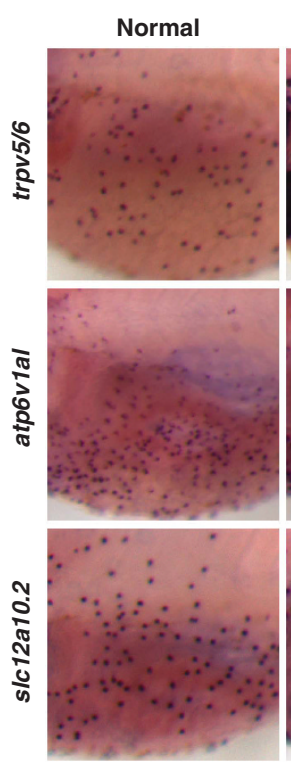

C

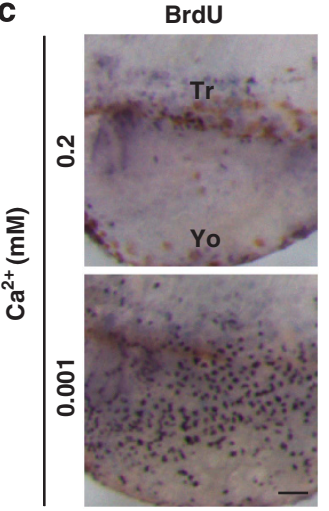

Low $\mathrm{Ca}^{2+}$

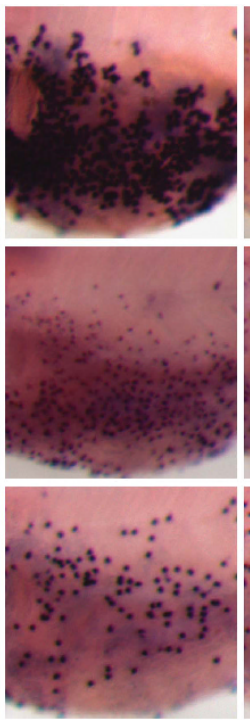

Low $\mathrm{Na}^{+}$

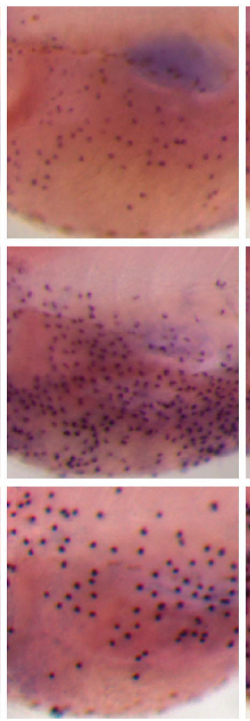

d

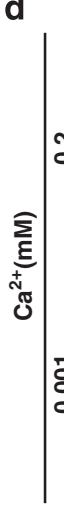

$\operatorname{trp} v 5 / 6$

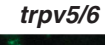

BrdU
Low $\mathrm{Cl}^{-}$

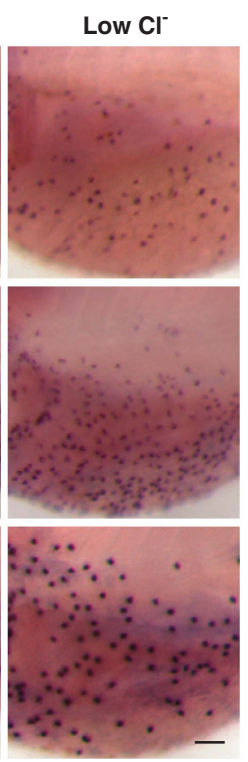

พุ่
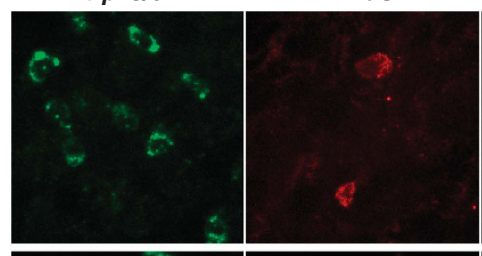
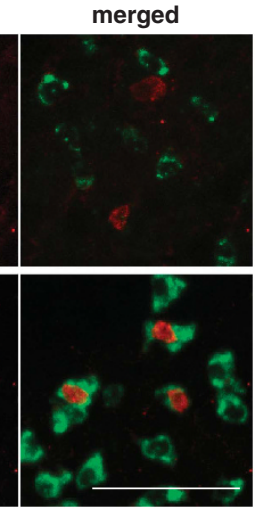

b

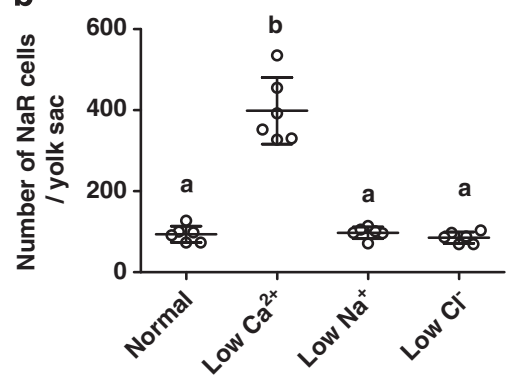

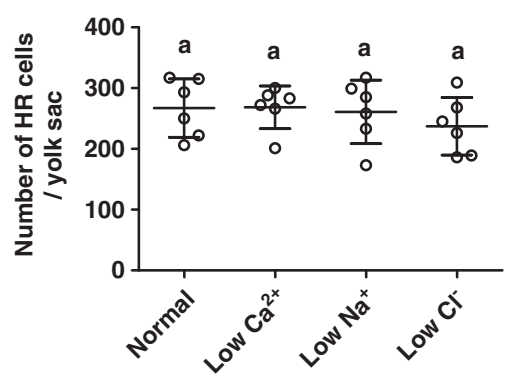

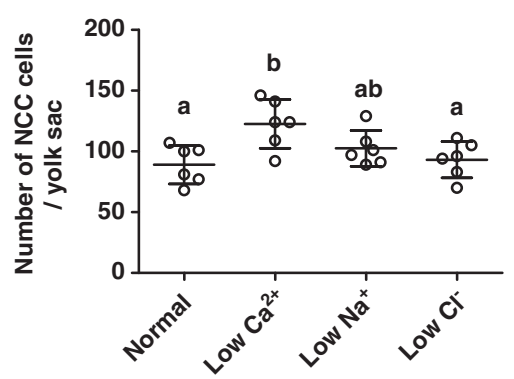

Figure 1 Low $\left[\mathrm{Ca}^{2+}\right]$ treatment increases NaR cell number and density on the larval yolk sac by reactivating a mitotic program in pre-existing NaR cells. (a and $\mathbf{b}$ ) Low $\left[\mathrm{Ca}^{2+}\right]$ treatment increases $\mathrm{NaR}$ cell density and number on the larval yolk sac skin. Zebrafish larvae (72 hpf) were transferred to artificial freshwater containing low [Ca $\left.{ }^{2+}\right]$, low $\left[\mathrm{Na}^{+}\right]$, or low $\left[\mathrm{Cl}^{-}\right.$], raised to $120 \mathrm{hpf}$, and analyzed by in situ hybridization for the indicated genes. Representative views are shown in (a). Shown here and in all following figures are lateral views of the yolk sac region. Anterior to the left and dorsal up. Scale bar $=50 \mu \mathrm{m}$. The total number of ionocytes on one side of the yolk sac was manually counted and shown in (b). Each dot represents an individual fish. Mean \pm S.D., $n=6$. Groups labeled with different letters are significantly different from each other $(P<0.05)$. (c) Low $\left[\mathrm{Ca}^{2+}\right]$ treatment increases cell proliferation. Larvae (72 hpf) were transferred to artificial freshwater with the indicated [Ca $\left.{ }^{2+}\right]$. BrdU (10 mM) was added at $96 \mathrm{hpf}$. The larvae were raised to $120 \mathrm{hpf}$ and stained using a BrdU antibody. Tr, trunk; Yo, yolk sac. (d) The mitotic cells under low [ $\mathrm{Ca}^{2+}$ ] are NaR cells. $72 \mathrm{hpf}$ larvae were transferred to artificial freshwater with the indicated $\left[\mathrm{Ca}^{2+}\right]$ and raised to $120 \mathrm{hpf}$. BrdU $(10 \mathrm{mM})$ was added $30 \mathrm{~min}$ before sampling. The larvae were analyzed by trpv5/6 mRNA in situ hybridization (green) and BrdU staining (red)

$n=95)$. The pAkt signal began to appear 30 min after larvae were transferred to $0.001 \mathrm{mM}\left[\mathrm{Ca}^{2+}\right]$ water (Figure 3c). After $48 \mathrm{~h}$, the pAkt signal was observed in clustered and likely newly divided cells (Figure $3 c$, see insert). To test whether this $\mathrm{Ca}^{2+}$ deficiency-induced Akt activation is downstream of the IGF1R, two structurally distinct IGF1R inhibitors, BMS- $754807^{19}$ and NVP-AEW54 $1^{20}$ were used. Blockage of the IGF1R-mediated signaling abolished pAkt signal under low $\left[\mathrm{Ca}^{2+}\right]$ (Figures $3 \mathrm{~d}$ and e). Likewise, the pAkt signal was eliminated by the addition of two distinct PI3K inhibitors, wortmannin and LY294002 (Figures 3d and e). However, neither SU5402 nor AG1478 had any inhibitory effect on low $\left[\mathrm{Ca}^{2+}\right]$-induced Akt signaling (Figures $3 d$ and e), although they were effective in inhibiting FGF receptor (Supplementary Figure S3a) and EGF receptor signaling (Supplementary Figure S3b) at the doses used. Furthermore, addition of EGTA, a $\mathrm{Ca}^{2+}$ chelating agent, to normal $\left[\mathrm{Ca}^{2+}\right]$ water, caused a similar increase in the pAkt levels (Figure $3 f$ ), ruling out the possibility that the observed pAkt in NaR cells was due to changes in osmolarity.

In comparison to the robust increase in pAkt signal, low $\left[\mathrm{Ca}^{2+}\right]$ treatment had no notable effect on pErk levels (Supplementary Figure S4a). While the basal pErk signal was abolished by the addition of U0126 or PD98059 (two MEK inhibitors), addition of the IGF1R inhibitor BMS-754807 and NVP-AEW541 had no such effect (Supplementary Figure S4b and $\mathrm{S} 4 \mathrm{c})$. These results suggest that low $\left[\mathrm{Ca}^{2+}\right]$ has no effect on the MEK-Erk signaling and that the basal pErk activity is independent from the IGF1R. 

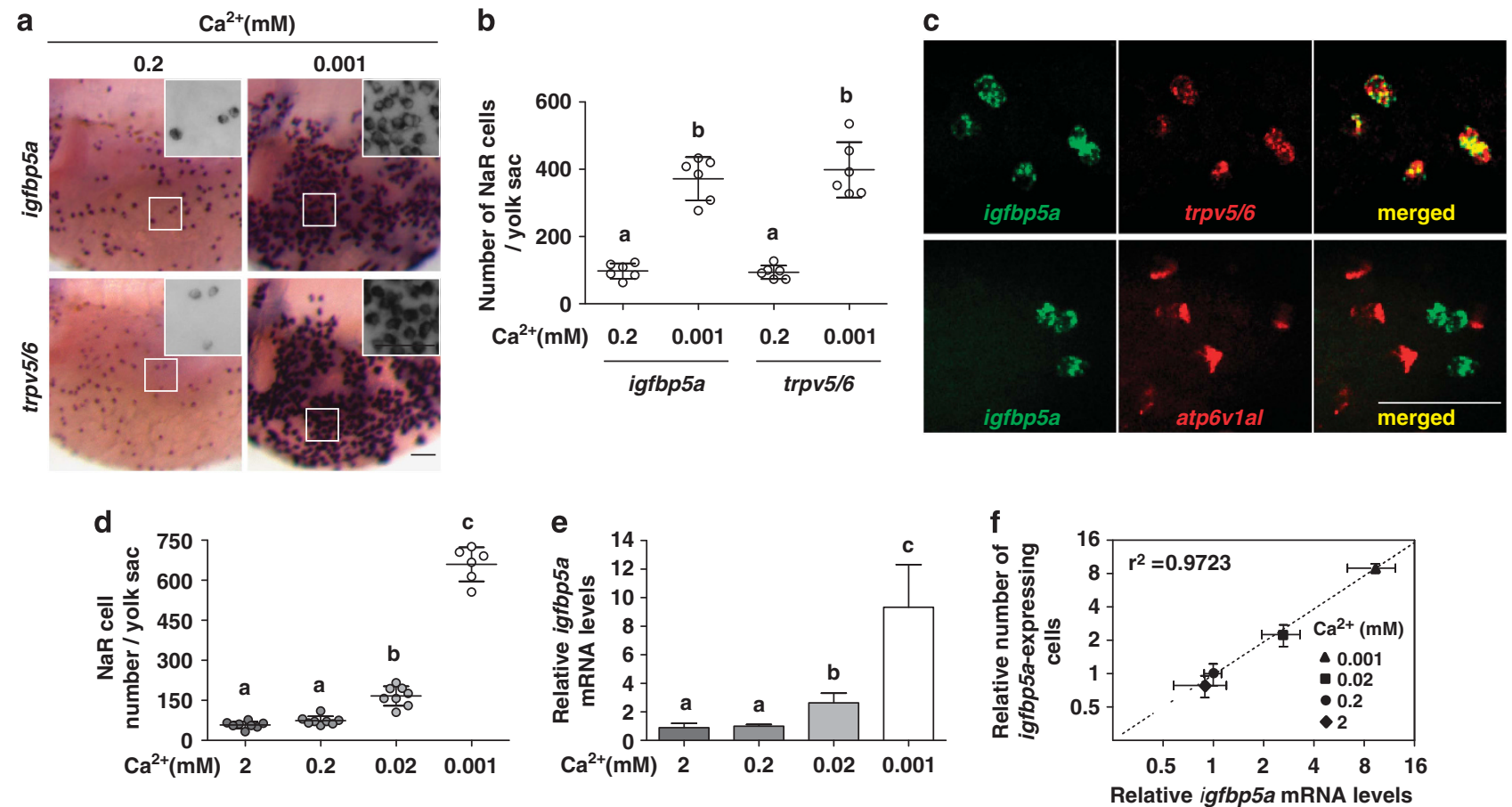

Figure 2 Zebrafish igfbp5a mRNA is specifically expressed in NaR cells and its levels are correlated with NaR cell number. (a and $\mathbf{b})$ Low $\left[\mathrm{Ca}{ }^{2+}\right.$ ] treatment results in similar increases in the number of igfbp5a mRNA-expressing cells and trpv5/6 mRNA-expressing cells. Zebrafish larvae (72 hpf) were transferred to artificial freshwater with the indicated $\left[\mathrm{Ca}^{2+}\right]$, raised to $120 \mathrm{hpf}$, and analyzed by in situ hybridization for the indicated genes. Representative views are shown in (a). Inserts are higher magnification views. The number of igfbp5a mRNA- and trpv5/6 mRNA-labeled cells on the yolk sac was manually counted and shown in (b). Each dot represents an individual fish. Mean \pm S.D., $n=6$. Groups labeled with different letters are significantly different from each other $(P<0.05)$. (c) Double-label in situ hybridization analysis of igfbp5a mRNA and trpv5/6 mRNA in zebrafish larvae. Upper panel shows a representative result. Lower panel is a representative result of igfbp5a mRNA (green) and atp6v1almRNA (red). (d) Relationship between NaR cell number and $\left[\mathrm{Ca}^{2+}\right]$. Zebrafish embryos were raised in artificial freshwater with the indicated varying $\left[\mathrm{Ca}^{2+}\right]$. NaR cells were analyzed by in situ hybridization of igfbp5a mRNA, and their number counted manually. Data shown are mean \pm S.D., $n=6-8$. (e) Relationship between igfbp5a mRNA levels and [Ca ${ }^{2+}$ ]. Total RNA was isolated from $120 \mathrm{hpf}$ larvae raised as in (d). The igfbp5a mRNA levels were measured by qRT-PCR and normalized by the $\beta$-actin levels. Mean \pm S.D., $n=3$. (f) Correlation analysis of NaR cell number and igfbp5a mRNA levels

IGF1R-PI3K-Akt signaling is required for NaR cell proliferation. The fact that igfbp5a mRNA is specifically expressed in $\mathrm{NaR}$ cells prompted us to investigate its potential role in the low $\left[\mathrm{Ca}^{2+}\right]$-induced IGF signaling in $\mathrm{NaR}$ cells. For this, antisense morpholinos (MOs) were designed, and their effectiveness and specificity in knocking down Igfbp5a were verified (Supplementary Figure S5). Knockdown of Igfbp5a markedly reduced low $\left[\mathrm{Ca}^{2+}\right]$ induced pAkt (Figures $4 a$ and b). To confirm that zebrafish igfbp5a indeed encodes a functional IGF binder, we constructed an Igfbp5a-GFP expression plasmid and an Igfbp5a-Myc plasmid and transfected them into HEK293T cells. Zebrafish Igfbp5a was capable of binding to IGF-1 or IGF-2, albeit with somewhat lower activity compared with human IGFBP5 (Figure 4c). These results indicate that local Igfbp5a has a positive role in the low $\left[\mathrm{Ca}^{2+}\right]$-induced IGF signaling in $\mathrm{NaR}$ cells, likely by binding to available IGF ligands and facilitating their interaction with the IGF1R.

Next, we investigated whether the activated IGF1R-PI3KAkt signaling is required for low $\left[\mathrm{Ca}^{2+}\right]$-induced $\mathrm{NaR}$ cell proliferation. A pharmacological approach was taken because MO knockdown of IGF1R causes embryonic death. ${ }^{21}$ Blockage of IGF1R-mediated signaling by BMS-754807 or NVP-AEW541 reduced the low $\left[\mathrm{Ca}^{2+}\right]$-induced increase in $\mathrm{NaR}$ cell density in 92 and $79 \%$ of the larvae examined (Figures $4 \mathrm{~d}$ and e) and abolished the low $\left[\mathrm{Ca}^{2+}\right]$-induced increase in igfbp5a mRNA levels (Figure 4f). Addition of wortmannin or LY294002 reduced the low $\left[\mathrm{Ca}^{2+}\right]$-induced $\mathrm{NaR}$ cell proliferation in 100 and $73 \%$ of the fish examined, whereas U0126 or PD98059 had no effect (Figure 4g). Likewise, inhibition of Akt by Akti-1/2 and MK2206 blocked the low $\left[\mathrm{Ca}^{2+}\right]$-induced increase in $\mathrm{NaR}$ cell density (Figure 4g) and igfbp5a mRNA levels (Figure 4h). These results demonstrate that the activities of IGF1R, $\mathrm{PI} 3 \mathrm{~K}$, and Akt are required for the low $\left[\mathrm{Ca}^{2+}\right]$-induced $\mathrm{NaR}$ cell proliferation.

Loss of Trpv5/6 results in IGF1R-PI3K-Akt activation in $\mathrm{NaR}$ cells and increased $\mathrm{NaR}$ cell proliferation under normal $\left[\mathrm{Ca}^{2+}\right]$. As the trpv5/6 gene is specifically expressed in NaR cells, and because Trpv5/6 is a $\mathrm{Ca}^{2+}$. selective cation channel, we speculated that Trpv5/6 might have a role in $\mathrm{NaR}$ cell proliferation. This hypothesis was tested using the Matt-und-schlapp (mus) mutant larvae, a trpv5/6 loss-of-function mutant zebrafish line. The mus mutant fish had impaired $\mathrm{Ca}^{2+}$ influx and significantly lower body $\mathrm{Ca}^{2+}$ content. $^{8}$ When exposed to low $\left[\mathrm{Ca}^{2+}\right]$, all mus mutant larvae died, while their siblings remained viable. ${ }^{8}$ Under normal $\left[\mathrm{Ca}^{2+}\right]$, the mus mutant larvae had a dramatic increase in NaR cell number and pAkt-positive cells compared with their siblings (Figures $5 a-d$ ). The increases in Akt signaling and $\mathrm{NaR}$ cells are IGF1R-dependent 
a

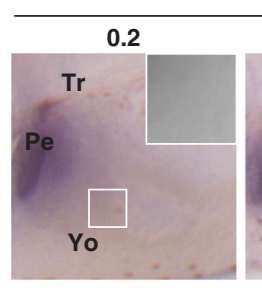

b

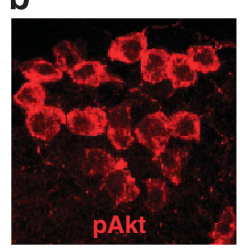

c

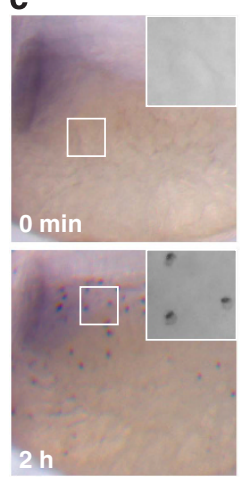

$\mathrm{Ca}^{2+}(\mathrm{mM})$ 0.02
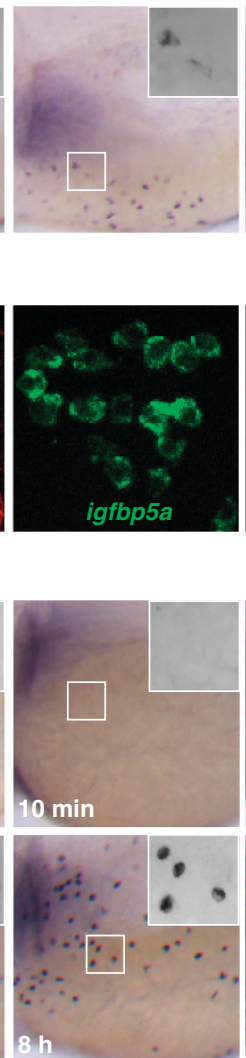
0.001
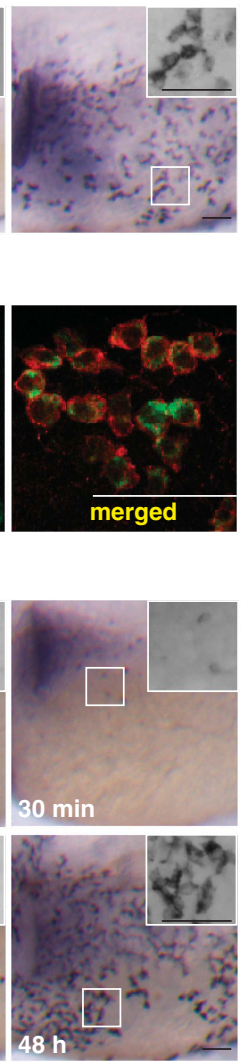

d
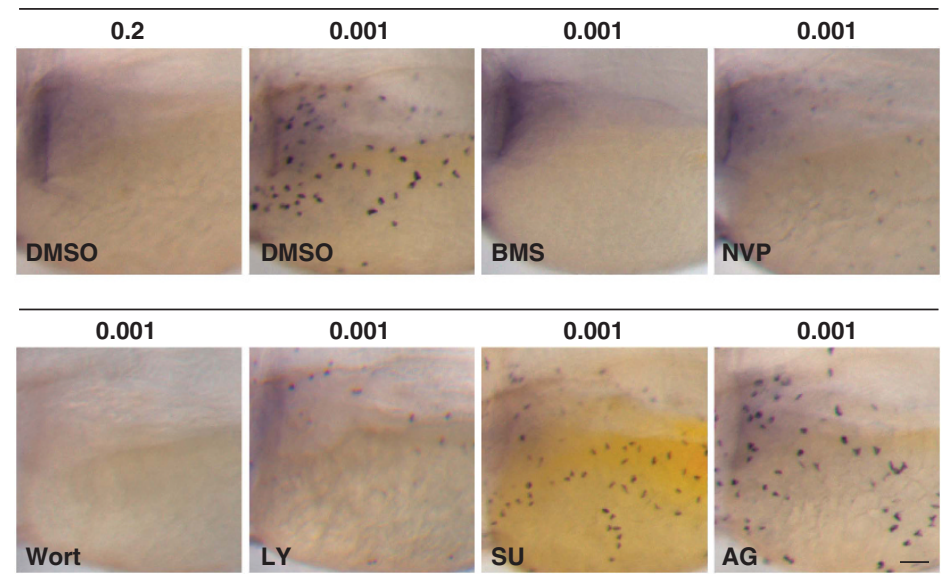

e

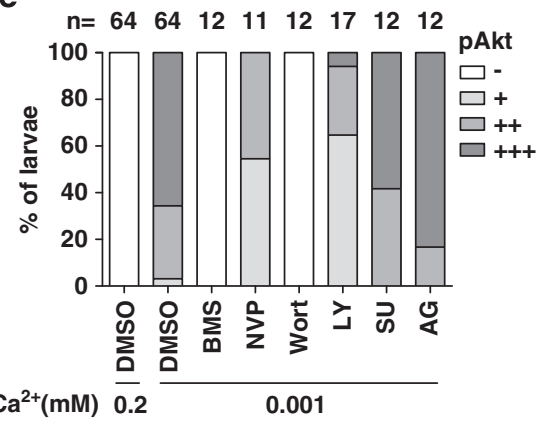

f

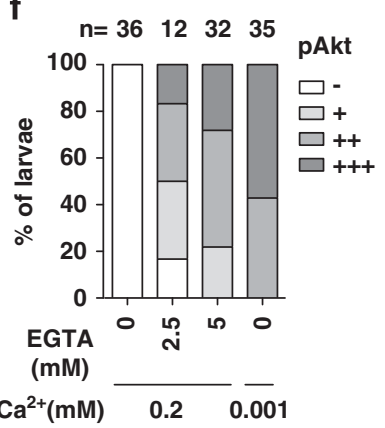

Figure 3 Low $\left[\mathrm{Ca}^{2+}\right.$ ] treatment results in a rapid and sustained activation of IGF-PI3K-Akt in NaR cells. (a) Low $\left[\mathrm{Ca}^{2+}\right.$ ] treatment induces the activation of phospho-Akt (pAkt) in yolk sac cells. Larvae (72 hpf) were transferred to artificial freshwater with the indicated $\left[\mathrm{Ca}^{2+}\right.$ ], raised to $120 \mathrm{hpf}$, and stained for pAkt. Inserts are higher magnification views. Tr, trunk; Pe, pectoral fin; Yo, yolk sac. Scale bar $=50 \mu \mathrm{m}$. (b) All pAkt-positive cells are NaR cells. Larvae (72 hpf) were transferred to artificial freshwater containing $0.001 \mathrm{mM}\left[\mathrm{Ca}^{2+}\right]$. After $48 \mathrm{~h}$, they were analyzed by in situ hybridization for igfbp5a mRNA and pAkt immunostaining. (c) Time course effect. Larvae (72 hpf) were transferred to artificial freshwater containing $0.001 \mathrm{mM}\left[\mathrm{Ca}^{2+}\right]$, sampled at the time points indicated, and stained for pAkt. Inserts are higher magnification views. (d and e) The low $\left[\mathrm{Ca}^{2+}\right.$-induced pAkt activation is IGF1R- and PI3K-dependent. Larvae (72 hpf) were transferred to $0.001 \mathrm{mM}\left[\mathrm{Ca}^{2+}\right.$ ] water containing DMSO, BMS-754807 (BMS, $0.3 \mu \mathrm{M}$ ), NVP-AEW541 (NVP, $6 \mu \mathrm{M}$ ), wortmannin (Wort, $0.06 \mu \mathrm{M}$ ), LY294002 (LY, $5 \mu \mathrm{M})$, SU5402 (SU, $15 \mu \mathrm{M})$, or AG1478 (AG, $4 \mu \mathrm{M})$. After $8 \mathrm{~h}$, they were stained for pAkt. Representative views are shown in (d). The animals were scored according to the scoring system shown in Supplementary Figure S1a and the quantitative results from three independent experiments are shown in (e). The total number of fish analyzed is shown on the top of each column. (f) Effect of EGTA on pAkt. $72 \mathrm{hpf}$ larvae were transferred to $0.2 \mathrm{mM}\left[\mathrm{Ca}^{2+}\right]$ water containing the indicated concentrations of EGTA. After $8 \mathrm{~h}$, they were stained for pAkt. The quantitative results are shown. Fish larvae raised in $0.001 \mathrm{mM}\left[\mathrm{Ca}^{2+}\right]$ water were used as controls

because they were abolished by the addition of BMS-754807 (Figures 5a-d). The pAkt-positive cells were often clustered, a phenotype resembling the dividing $\mathrm{NaR}$ cells seen in low $\left[\mathrm{Ca}^{2+}\right]$-treated wild-type larvae. Indeed, BrdU-labeling experiments showed a highly elevated $\mathrm{NaR}$ cell proliferation rate. While none of the NaR cells in the sibling group were BrdU-positive under normal $\left[\mathrm{Ca}^{2+}\right](n=60), 30 \%$ of $\mathrm{NaR}$ cells in the mus mutants were BrdU-positive $(n=98)$ under normal $\left[\mathrm{Ca}^{2+}\right]$ (Figure 5e). As an independent and complementary approach, we performed MO knockdown using a validated Trpv5/6 targeting $\mathrm{MO}^{22}$ Compared with the standard control MO-injected group, the Trpv5/6 targeting MO-injected group had elevated pAkt levels and increased $\mathrm{NaR}$ cell number, although the penetrance was lower (Figures $5 f$ and $g$ ). These results suggest that Trpv5/6 represses IGF signaling in $\mathrm{NaR}$ cells under normal $\left[\mathrm{Ca}^{2+}\right]$, and a loss of Trpv5/6 function or protein expression leads to a hyperactivation of IGF signaling in $\mathrm{NaR}$ cells and increases their proliferation under normal $\left[\mathrm{Ca}^{2+}\right]$.
Trpv5/6 represses IGF signaling under normal $\left[\mathrm{Ca}^{2+}\right]$ but activates IGF signaling under low $\left[\mathrm{Ca}^{2+}\right]$. Next, four commonly used TRPV5/6 inhibitors/blockers, lanthanum, gadolinium, ruthenium red, and cadmium, were used to further investigate the role of Trpv5/6 in regulating IGF signaling in $\mathrm{NaR}$ cells under normal and low $\left[\mathrm{Ca}^{2+}\right]$. Addition of these TRPV5/6 inhibitors to normal $\left[\mathrm{Ca}^{2+}\right]$ water resulted in an increased number of pAkt-positive cells on the yolk sac (Figures 6a-d). This effect was most obvious with lanthanum and gadolinium. These data, in agreement with the genetic data described above, indicate that Trpv5/6 represses IGF signaling in NaR cells under normal $\left[\mathrm{Ca}^{2+}\right]$.

Unexpectedly, when these TRPV5/6 inhibitors were added to the low $\left[\mathrm{Ca}^{2+}\right]$ group, they all inhibited low $\left[\mathrm{Ca}^{2+}\right]$-induced Akt activation (Figures $6 a-d)$. Cadmium was the most potent among them. In comparison, the L-type $\mathrm{Ca}^{2+}$ channel blocker verapamil and the potassium channel blocker tetraethylammonium had no such effect (Supplementary Figure S6a). Furthermore, addition of cadmium reduced the low $\left[\mathrm{Ca}^{2+}\right]-$ 

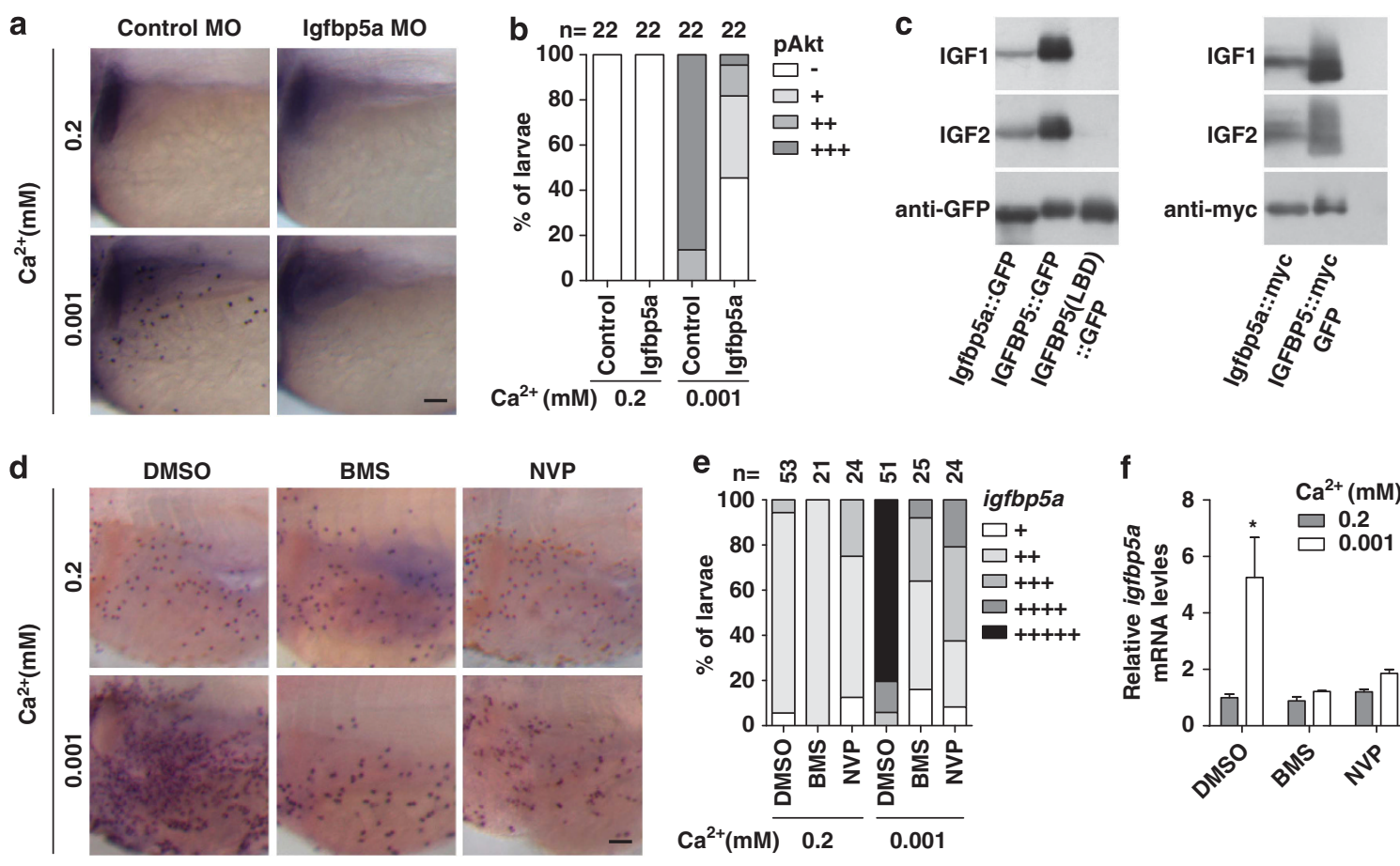

NVP
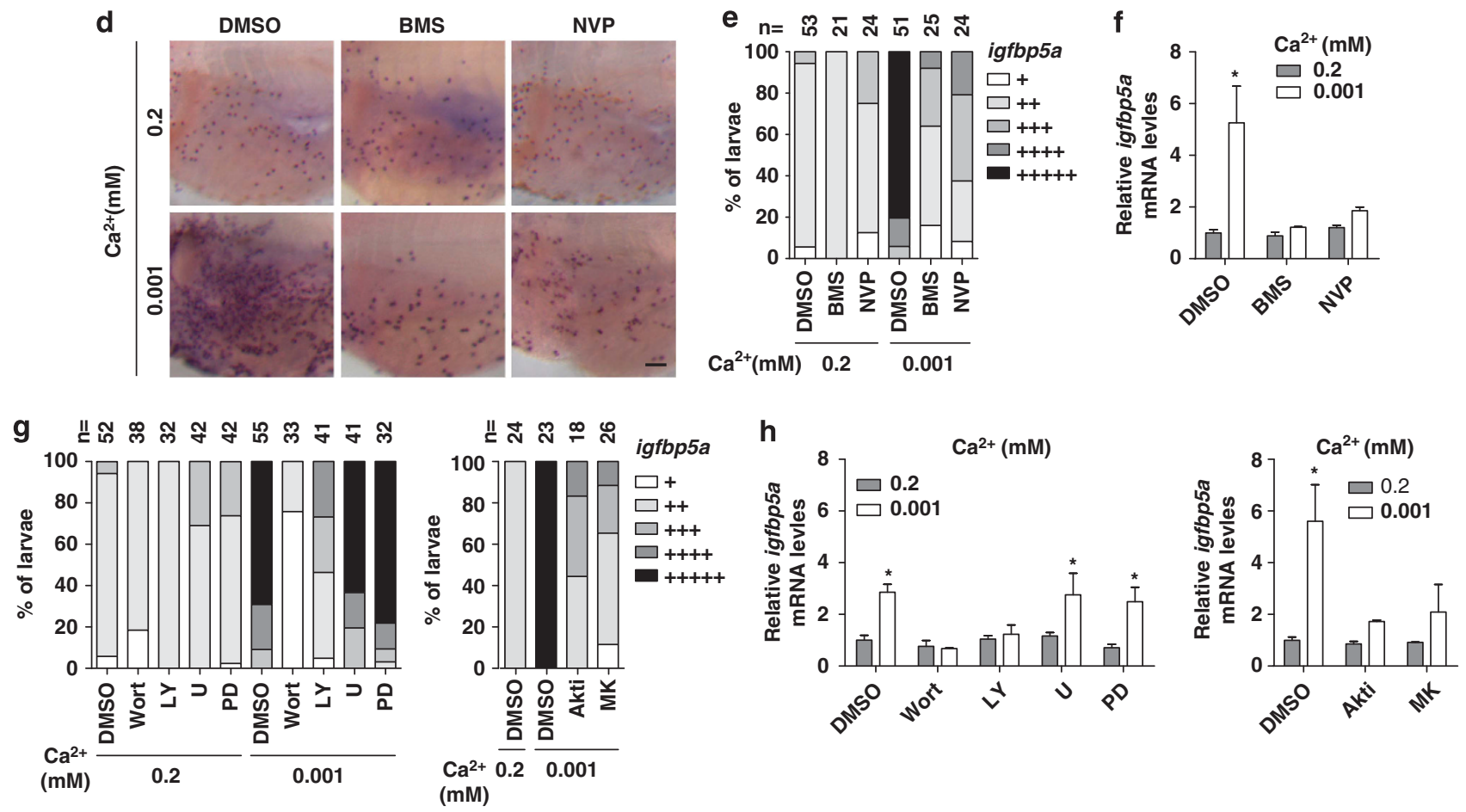

Figure 4 Local Igfbp5a facilitates [ $\mathrm{Ca}^{2+}$ ]-induced IGF signaling activation and IGF signaling is required for low [Ca ${ }^{2+}$ ]-induced NaR cell proliferation. (a and b) Igfbp5a knockdown inhibits low $\left[\mathrm{Ca}^{2+}\right.$ ]-induced Akt signaling. Embryos injected with control $\mathrm{MO}$ or lgfbp5a targeting MOs were transferred to water with the indicated $\left[\mathrm{Ca}^{2+}\right]$ at $72 \mathrm{hpf}$ and fixed $2 \mathrm{~h}$ later for pAkt staining. Representative views are shown in (a) and quantitative results in (b). Scale bar $=50 \mu \mathrm{m}$. The total number of fish analyzed from three independent experiments is shown on the top of each column. (c) Zebrafish igfbp5a encodes a secreted protein that binds IGFs. Conditioned media were prepared from HEK293 cells transfected with expression plasmids encoding the indicated proteins. They were analyzed by ligand blot with DIG-labeled IGF-1 or IGF-2, and by western blot using the indicated antibody. LBD, ligand binding domain mutant. (d and e) Inhibition of IGF1R abolishes low [Ca ${ }^{2+}$ ]-induced increase in NaR cells. Larvae (72 hpf) were transferred to $0.2 \mathrm{mM}$ or $0.001 \mathrm{mM}\left[\mathrm{Ca}^{2+}\right.$ ] water containing DMSO, BMS-754807 (BMS, $0.3 \mu \mathrm{M}$ ), or NVP-AEW541 (NVP, $2 \mu \mathrm{M}$ ), and raised to $120 \mathrm{hpf}$. NaR cells were labeled by in situ hybridization for igfbp5a mRNA. Representative views are shown in (d). The animals were scored according to the scoring system shown in Supplementary Figure S1c and the results are shown in (e). (f) Effect of IGF1R inhibition on igfbp5a mRNA levels. The experimental groups were the same as described in (d). The mRNA levels of igfbp5a were measured by qRT-PCR and normalized by the $\beta$-actin levels. Values shown are mean \pm S.D., $n=3$. ${ }^{*} P<0.001$ compared with the corresponding $0.2 \mathrm{mM}\left[\mathrm{Ca}^{2+}\right.$ ] control group. (g) Effects of PI3K, Akt, and MEK inhibitors. Larvae (72 hpf) were transferred to $0.2 \mathrm{mM}$ or $\left.0.001 \mathrm{mM}^{2} \mathrm{Ca}^{2+}\right]$ water containing DMSO, Wortmannin $(0.06 \mu \mathrm{M})$, LY294002 (5 $\mu \mathrm{M})$, U0126 (U, $10 \mu \mathrm{M})$, PD98059 (PD, $10 \mu \mathrm{M})$, Akti-1/2 (Akti, $5 \mu \mathrm{M})$, or MK2206 (MK, $2 \mu \mathrm{M})$, and raised to $120 \mathrm{hpf}$. NaR cell density was determined as described in (e). (h) Effects of blocking PI3K, Akt, and MEK on igfbp5a mRNA levels. The experimental groups were the same as described in (g). The igfbp5a mRNA levels were measured by qRT-PCR and normalized by the $\beta$-actin levels. Mean \pm S.D., $n=3 .{ }^{*} P<0.001$ compared to the corresponding $0.2 \mathrm{mM}\left[\mathrm{Ca}{ }^{2+}\right.$ ] control group

induced increase in $\mathrm{NaR}$ cell density in a concentrationdependent manner (Figure 6e), suggesting that inhibiting Trpv5/6 activity blocks low $\left[\mathrm{Ca}^{2+}\right]$-induced IGF signaling and reduces $\mathrm{NaR}$ cell proliferation. The specificity of these TRPV5/6 inhibitors/blockers was confirmed using the mus mutant larvae. While cadmium inhibited low $\left[\mathrm{Ca}^{2+}\right]$-induced pAkt activation in the control group, it did not affect the elevated pAkt levels in the mus mutant group under normal $\left[\mathrm{Ca}^{2+}\right]$ (Supplementary Figure S6b).
Intracellular $\mathrm{Ca}^{2+} / \mathrm{CaM}$-dependent signaling has been implicated in Akt activation in cultured mammalian cells. ${ }^{23}$ We tested the possible role of intracellular $\mathrm{Ca}^{2+}$ and/or CaM signaling in mediating the Trpv5/6 effect using the intracellular $\mathrm{Ca}^{2+}$ chelator BAPTA-AM. Addition of BAPTA-AM to low $\left[\mathrm{Ca}^{2+}\right]$ water did not affect Akt activity (Figure 6f). Likewise, addition of W7 and calmidazolium, two CaM antagonists, failed to inhibit the low $\left[\mathrm{Ca}^{2+}\right]$-induced Akt activation (Figure 6f). Trpv5/6 is a $\mathrm{Ca}^{2+}$-selective channel with nearly 
a

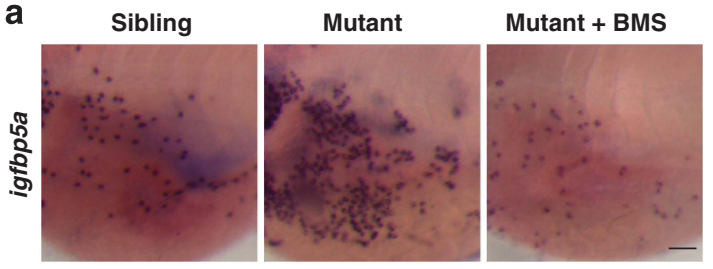

C
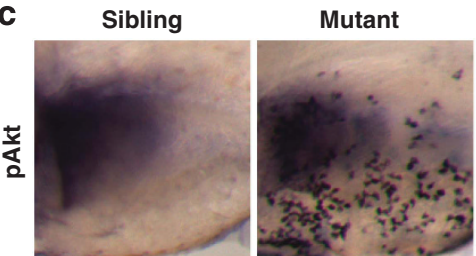

Mutant + BMS

e
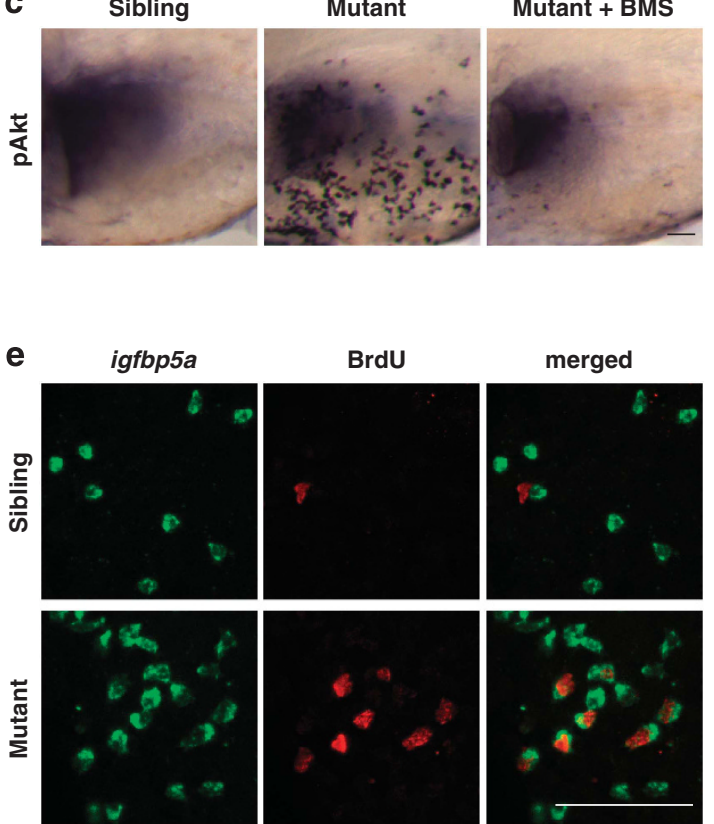

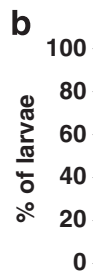

$\begin{array}{lll}27 & 13 & 10\end{array}$

igfbp5a

$\square+$

$\square++$

$\square+++$

$\square++++$

ש+++++

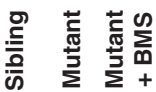
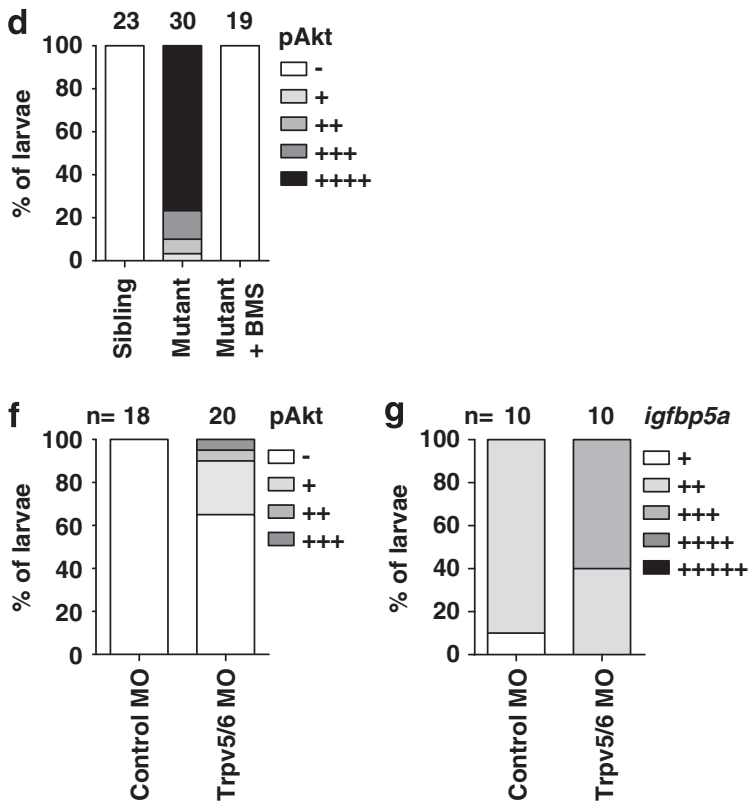

Figure 5 Loss of Trpv5/6 results in IGF-PI3K-Akt activation and increased NaR cell proliferation under normal $\left[\mathrm{Ca}^{2+}\right]$. (a and $\left.\mathbf{b}\right)$ Elevated NaR cell number and density in the mus (loss-of-function trpv5/6) mutant larvae under normal $\left[\mathrm{Ca}^{2+}\right]$. Homozygous mus embryos and their siblings were raised in $0.2 \mathrm{mM}\left[\mathrm{Ca}^{2+}\right]$ water. DMSO or $0.3 \mu \mathrm{M}$ BMS-754807 was added at $24 \mathrm{hpf}$. At $120 \mathrm{hpf}$, fish were fixed and NaR cells were labeled by in situ hybridization for igfbp5a mRNA. Representative views are shown in (a) and quantitative results from three independent experiments in (b). (c and d) Elevated Akt signaling in the mus mutant larvae. The experimental groups were the same as described in (a). pAkt-positive cells were labeled and scored according to Supplementary Figure S1d. Representative views are shown in (c) and quantitative results are shown in (d). (e) Elevated NaR cell proliferation in the mus mutant fish. Homozygous mus embryos and their siblings were raised in $0.2 \mathrm{mM}\left[\mathrm{Ca}^{2+}\right]$ water. At $120 \mathrm{hpf}$, they were fixed and analyzed by in situ hybridization for igfbp5a mRNA and BrdU staining after a 30 min pulse of BrdU (10 mM) prior to the sampling. (f and $\mathbf{g}) \mathrm{Knockdown}$ of Trpv5/6 results in increased pAkt-positive cells (f) and igfbp5a mRNA-expressing NaR cells (g). Embryos injected with control or Trpv5/6 targeting MOs were raised in $0.2 \mathrm{mM}\left[\mathrm{Ca}^{2+}\right.$ ] water. pAkt-positive cells (f) and NaR cells (g) were labeled and scored at 72 and $120 \mathrm{hpf}$ as described above

complete inward rectification that can induce membrane depolarization. ${ }^{24,25}$ Adding $100 \mathrm{mM} \mathrm{KCl}$ to normal $\left[\mathrm{Ca}^{2+}\right.$ ] water to evoke artificial depolarization mimicked the effect of low $\left[\mathrm{Ca}^{2+}\right]$ and strongly increased pAkt levels (Figure $6 \mathrm{~g}$ ). This effect was not caused by changes in osmolarity because addition of sorbitol or NMDG at equal molar concentrations had no such effect (Figure $6 \mathrm{~g}$ ). The $\mathrm{KCl}$-induced Akt activation was abolished by the addition of BMS-754807 and Wortmannin (Figure $6 \mathrm{~g}$ ), suggesting that membrane depolarization activates Akt signaling in an IGF1R- and PI3K-dependent manner. If the Trpv5/6-dependent IGF signaling in NaR cells were mediated through membrane depolarization, then $\mathrm{KCl}$ treatment should reverse the inhibitory effects of Trpv5/6 blockers. Indeed, $\mathrm{KCl}$ treatment reversed the inhibitory effects of ruthenium red and cadmium on low $\left[\mathrm{Ca}^{2+}\right]$-induced Akt activation (Figure 6h). These results suggest that the Trpv5/6 activity-dependent increase in IGF signaling under low $\left[\mathrm{Ca}^{2+}\right]$ is likely mediated through membrane depolarization.
Low extracellular $\left[\mathrm{Ca}^{2+}\right]$ enhances IGF signaling in human colon cancer cells. Human Caco-2 cells were used to test whether low extracellular $\left[\mathrm{Ca}^{2+}\right]$ amplifies IGF signaling in human colon cells. These colon carcinoma cells expressed TRPV6 ${ }^{26}$ (Supplementary Figure S7a) and showed increased Akt signaling in response to IGF stimulation (Figure 7a). This effect is mediated through IGF1R because it was inhibited by BMS-754807 and NVP-AEW541 (Figure 7a). FACS analysis showed that while IGF stimulation resulted in a significant increase in the number of cells in the S-phase in the low $\left[\mathrm{Ca}^{2+}\right]$ group $(P<0.001)$, it had no such effect in the normal $\left[\mathrm{Ca}^{2+}\right]$ group (Figure $\left.7 \mathrm{~b}\right)$. These data suggest that low extracellular $\left[\mathrm{Ca}^{2+}\right]$ enhances the mitotic response of Caco- 2 cells to IGF stimulation.

Next, we tested whether low extracellular $\left[\mathrm{Ca}^{2+}\right]$ enhances IGF1R-PI3K-Akt signaling. IGF-1 or IGF-2 caused a significantly greater Akt activation in the low $\left[\mathrm{Ca}^{2+}\right]$ group $(6.5 \pm 0.4$-fold $)$ than in the normal $\left[\mathrm{Ca}^{2+}\right]$ group $(2.8 \pm 0.6-$ 
a
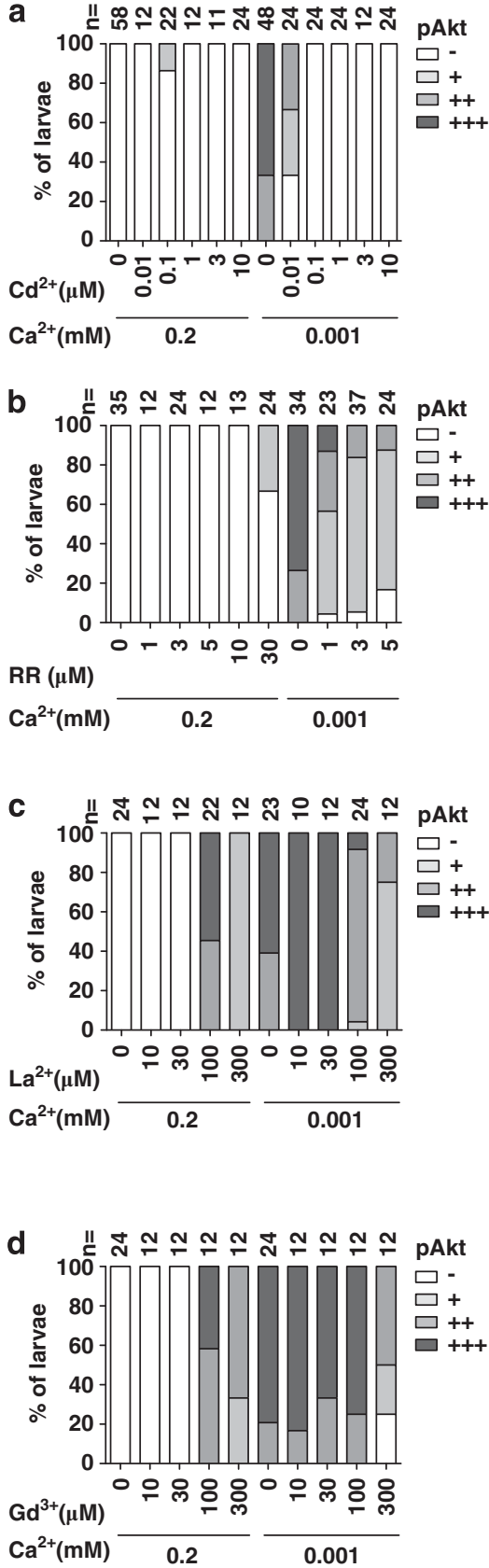

e
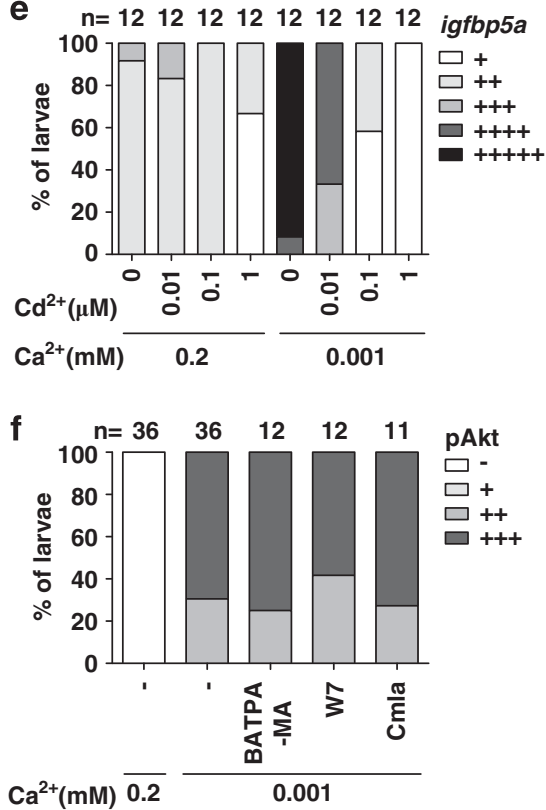

g
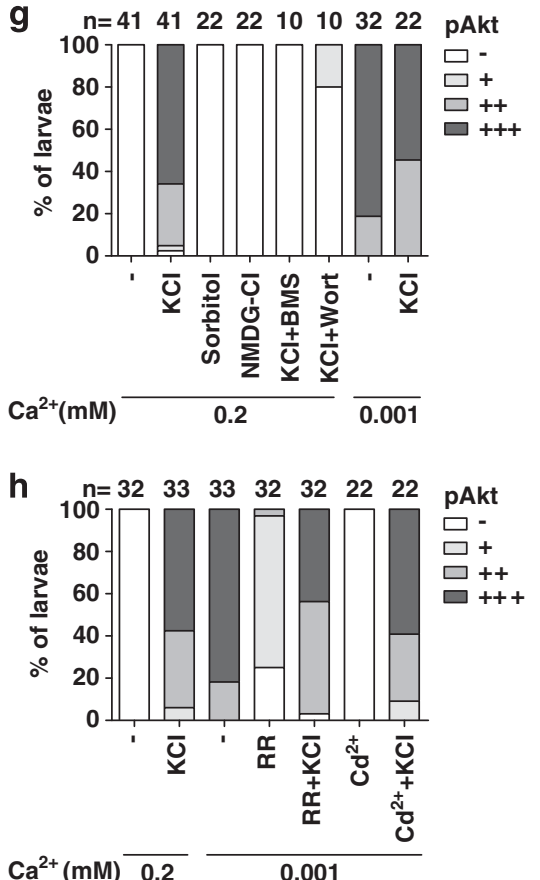

Figure 6 Trpv5/6 has different roles in regulating IGF-PI3K-Akt signaling under normal and low $\left[\mathrm{Ca}^{2+}\right]$. (a-d) Effects of cadmium $\left(\mathrm{Cd}^{2+}\right)$, ruthenium red (RR), lanthanum $\left(\mathrm{La}^{3+}\right)$, and gadolinium $\left(\mathrm{Gd}^{3+}\right)$ on pAkt. Larvae (72 hpf) were transferred to $0.2 \mathrm{mM}$ or $0.001 \mathrm{mM}\left[\mathrm{Ca}^{2+}\right]$ water containing the indicated concentrations of the drugs. After $8 \mathrm{~h}$, they were stained for pAkt and scored. The total number of larvae analyzed from three independent experiments is shown on the top of each column. (e) Blockage of the Trpv5/ 6 channel abolishes the low $\left[\mathrm{Ca}^{2+}\right.$-induced increase in $\mathrm{NaR}$ cell density. Larvae $(72 \mathrm{hpf})$ were transferred to $0.2 \mathrm{mM}$ or $0.001 \mathrm{mM}\left[\mathrm{Ca}^{2+}\right]$ water containing the indicated concentrations of $\mathrm{Cd}^{2+}$. At $120 \mathrm{hpf}$, they were sampled and analyzed by in situ hybridization for igfbp5a. (f) The low $\left[\mathrm{Ca}^{2+}\right.$ ]-induced Akt signaling is not mediated by intracellular $\mathrm{Ca}^{2+} / \mathrm{CaM}$ signaling. Larvae (72 hpf) were transferred to $0.001 \mathrm{mM}\left[\mathrm{Ca}^{2+}\right.$ ] water containing BAPTA-AM (100 $\left.\mu \mathrm{M}\right)$, W7 (50 $\left.\mu \mathrm{M}\right)$, or Calmidazolium (Calm, $\left.1 \mu \mathrm{M}\right)$. After $8 \mathrm{~h}$, they were fixed, stained for pAkt, and scored as described earlier. (g) KCl treatment activates Akt signaling in an IGF1R and PI3K-dependent manner. Larvae (72 hpf) were transferred to $0.2 \mathrm{mM}$ or $0.001 \mathrm{mM}\left[\mathrm{Ca}^{2+}\right.$ ] water containing $\mathrm{KCl}(100 \mathrm{mM})$, sorbitol $(200 \mathrm{mM})$, NMDG-Cl $(100 \mathrm{mM})$, BMS $(0.3 \mu \mathrm{M})$, and Wortmannin $(0.06 \mu \mathrm{M})$, alone or in combination. After $2 \mathrm{~h}$, they were stained for pAkt. (h) KCl reverses the effect of Trpv5/6 blockage. Larvae (72 hpf) were transferred to $0.2 \mathrm{mM}$ or $0.001 \mathrm{mM}\left[\mathrm{Ca}^{2+}\right]$ water containing $\mathrm{KCl}(100 \mathrm{mM}), \mathrm{RR}(5 \mu \mathrm{M})$, and $\mathrm{Cd}^{2+}(1 \mu \mathrm{M})$, alone or in combination. After $2 \mathrm{~h}$, they were stained for pAkt

fold) $(P<0.001$, Figure 7c). In contrast, IGF treatment caused similar increases in the pIGF1R levels in the normal and low $\left[\mathrm{Ca}^{2+}\right]$ groups (Figure 7d). Furthermore, IGF treatment caused a highly significant increase in p85 and PDK1 phosphorylation in the low $\left[\mathrm{Ca}^{2+}\right]$ group but not in the normal $\left[\mathrm{Ca}^{2+}\right]$ group (Figures $7 e$ and $f$ and Supplementary Figure 


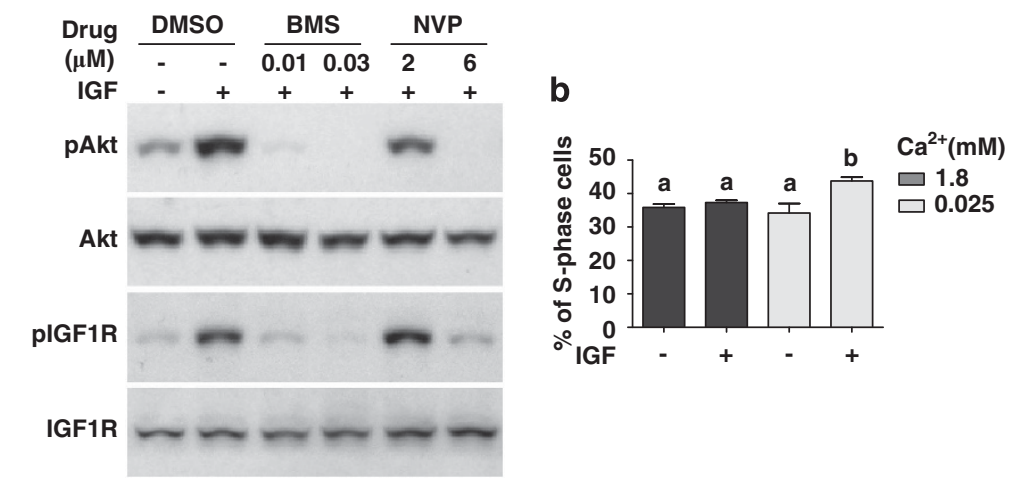

C

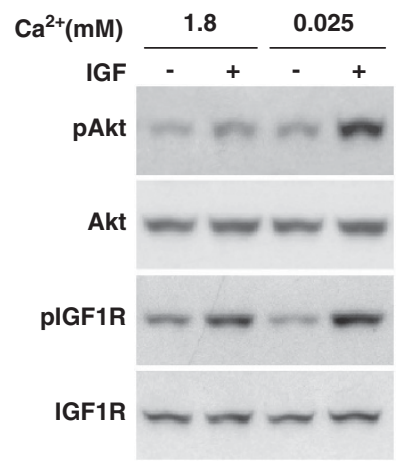

d $\quad \mathrm{Ca}^{2+}(\mathrm{mM})$

$$
8 \text { 口 } 1.8
$$

$\left.\begin{array}{r}8 \\ \text { ะ } 6\end{array}\right] \square .025$
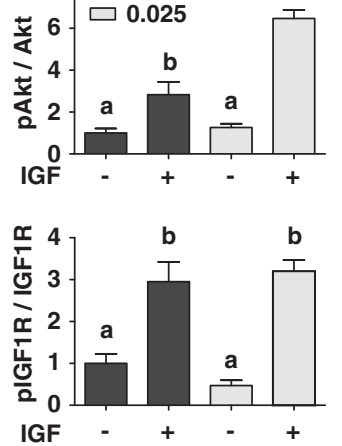
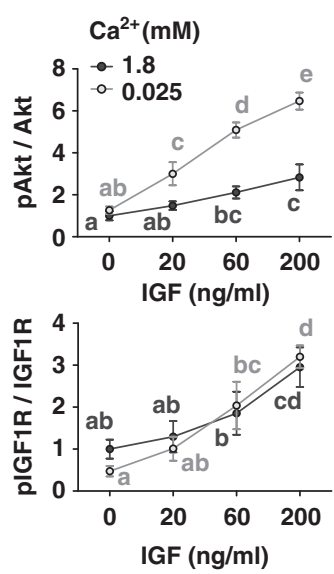

$$
\text { e }
$$
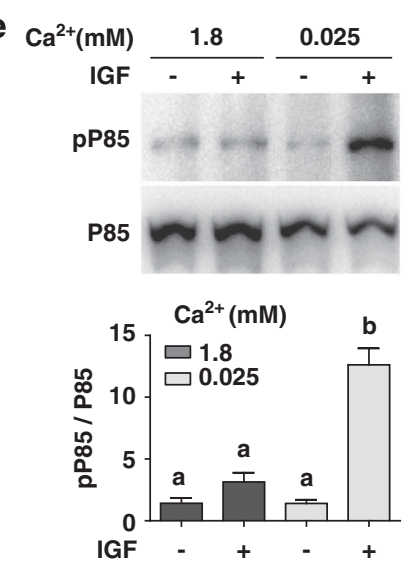
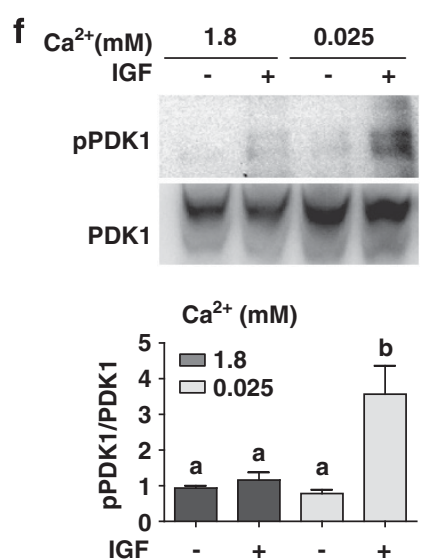

Figure 7 Low extracellular $\left[\mathrm{Ca}^{2+}\right.$ ] amplifies IGF signaling in human colon cells. (a) Caco-2 cells are responsive to IGF stimulation under low [Ca $\left.{ }^{2+}\right]$. Confluent $\mathrm{Caco-2}$ cells were incubated in serum-free medium containing $0.025 \mathrm{mM}\left[\mathrm{Ca}^{2+}\right.$ overnight together with the indicated inhibitors at the indicated concentrations. IGF-2 (200 ng/ml) was added. Cells were lysed $10 \mathrm{~min}$ later and analyzed by western blot using the indicated antibodies. Similar results were found with IGF-1 (100 ng/ml). (b) Low extracellular $\left[\mathrm{Ca}^{2+}\right]$ treatment increases the mitotic response to IGF stimulation. Confluent Caco-2 cells were incubated overnight in serum-free medium containing the indicated [Ca $\left.{ }^{2+}\right]$. They were treated with $500 \mathrm{ng} / \mathrm{ml} \mathrm{IGF-1}$ and analyzed by FACS $96 \mathrm{~h}$ later. The percentage of S-phase was calculated and shown. Values shown are mean \pm S.D., $n=3$. Groups labeled with different letters are significantly different from each other $(P<0.001)$. (c) Low $\left[\mathrm{Ca}^{2+}\right.$ ] amplifies IGF-induced Akt signaling. Confluent Caco-2 cells were incubated in serum-free medium containing the indicated $\left[\mathrm{Ca}^{2+}\right]$ overnight. IGF-2 $(200 \mathrm{ng} / \mathrm{ml})$ was added and cells were lysed 10 min later. The levels of pAkt, total Akt, pIGF1R, and total IGF1R were analyzed by western blot and their ratios calculated. Representative results are shown in the left panel and quantification results in the right panel. Values shown here and thereafter are mean \pm S.D., $n=3-4$. Groups sharing no common letters are significantly different from each other $(P<0.05)$. (d) Dosedependent effect of IGF-2 on Akt (upper panel) and IGF1R phosphorylation (lower panel). The cells were treated the same way as described in (c) with the indicated concentrations of IGF-2. (e) Low extracellular $\left[\mathrm{Ca}^{2+}\right.$ ] amplifies IGF-induced PI3K signaling. The experiments were the same as (c). Cell lysates (1 mg) were precipitated with the $4 \mathrm{G} 10$ antibody followed by western blot analysis using a p85 antibody. Total p85 levels were determined by western blot. Representative results are shown in the upper panel. The ratio of phospho-p85 and total p85 was calculated and shown in the lower panel. Reciprocal co-IP experiments showed similar results (Supplementary Figure S7b). (f) Low extracellular $\left[\mathrm{Ca}^{2+}\right.$ ] amplifies IGF-induced PDK1 signaling. Confluent Caco-2 cells were incubated in serum-free medium containing the indicated [Ca $\left.{ }^{2+}\right]$ overnight. IGF-1 $(500 \mathrm{ng} / \mathrm{ml})$ was added and cells were lysed $10 \mathrm{~min}$ later. The levels of phospho-PDK1 and total PDK1 were determined by co-IP experiments using the $4 \mathrm{G} 10$ antibody and a PDK1 antibody. Representative results are shown in the upper panel and quantitative results in the lower panel. IGF-2 treatment resulted in similar amplification of PDK1 signaling (Supplementary Figure S7c) 
S7b and S7c). These data suggest that the low $\left[\mathrm{Ca}^{2+}\right]-$ induced amplification occurs in a step downstream of the IGF1R but at or above PI3K.

To determine whether TRPV6 is involved in the low $\left[\mathrm{Ca}^{2+}\right]-$ induced amplification of IGF signaling in Caco-2 cells, ruthenium red and cadmium were used. Co-incubation with ruthenium red or cadmium decreased the IGF-2-induced increase in pAkt levels in a dose-dependent manner (Figures $8 a$ and b), while it did not inhibit IGF-induced IGF1R phosphorylation (Figures $8 \mathrm{c}$ and d). The $\mathrm{Ca}^{2+}$-sensing receptor (CaSR), a class C G-protein-coupled receptor that senses and is activated by high extracellular $\left[\mathrm{Ca}^{2+}\right]$, has a key role in maintaining $\mathrm{Ca}^{2+}$ homeostasis by regulating the release of parathyroid hormone $(\mathrm{PTH}){ }^{27}$ The CaSR is expressed in the entire digestive tract, including the colon, and has been hypothesized to be a major driver of colon cell differentiation under high extracellular $\left[\mathrm{Ca}^{2+}\right] .{ }^{28}$ However, addition of NPS 2143, a selective CaSR antagonist, ${ }^{29}$ to cultured Caco-2 cells did not affect IGF-induced Akt signaling in either normal or low $\left[\mathrm{Ca}^{2+}\right]$ conditions (Figure 8e). Likewise, NPS 2143 treatment had no effect on Akt signaling in NaR cells in zebrafish larvae (Figure 8f). Gene expression analysis results showed no difference in casr mRNA levels in zebrafish larvae raised in normal or low $\left[\mathrm{Ca}^{2+}\right]$ water (Figure $8 \mathrm{~g}$ ). These data argue against a role of $\mathrm{CaSR}$ in the low $\left[\mathrm{Ca}^{2+}\right]$-induced Akt signaling in Caco-2 in vitro or NaR cells in vivo.

\section{Discussion}

Human colon cancer cells proliferate when cultured in low extracellular $\left[\mathrm{Ca}^{2+}\right]$ and form colonies in soft agar under low $\left[\mathrm{Ca}^{2+}\right]$ conditions. When the extracellular $\left[\mathrm{Ca}^{2+}\right]$ level is increased to $1 \mathrm{mM}$ or higher, monolayer growth slows, colony formation in soft agar is suppressed, and cells undergo differentiation. ${ }^{30} \mathrm{High}\left[\mathrm{Ca}^{2+}\right]$ reduces the expression of cyclin D1, c-fos, c-myc, c-jun and other cell growth-promoting genes, and increases the expression of genes associated with the onset of differentiation, such as P27(Kip1), $\mathrm{P} 21(\mathrm{WAF} 1)$, and E-cadherin. ${ }^{30}$ Although the mechanistic basis underlying high $\left[\mathrm{Ca}^{2+}\right]$-induced epithelial cell differentiation is relatively well understood, how $\mathrm{Ca}^{2+}$ deficiency leads to abnormal cell proliferation is not very clear. Using zebrafish larval yolk sac skin as an experimental model, the present study uncovers a previously unrecognized signaling mechanism mediating low $\left[\mathrm{Ca}^{2+}\right]$-induced abnormal epithelial proliferation. We show that low $\left[\mathrm{Ca}^{2+}\right]$ treatment re-activates a mitotic program in pre-existing $\mathrm{NaR}$ cells. This action is specific to $\mathrm{Ca}^{2+}$ deficiency because reducing the concentration of other major ions has no such effect. We provide several lines of evidence suggesting that low $\left[\mathrm{Ca}^{2+}\right]$ treatment results in a strong and sustained activation of the IGF signaling pathway in these epithelial cells exclusively, which in turn stimulates these differentiated cells to re-enter the cell cycle. We show that the trpv5/6 and igfbp5a genes are specifically expressed in NaR cells. While locally expressed Igfbp5a has a positive role in activating IGF signaling by facilitating the IGF ligand and receptor binding, Trpv5/6 serves as a crucial switch of IGF signaling in NaR cells. Under normal $\left[\mathrm{Ca}^{2+}\right]$, Trpv5/6 represses IGF signaling in $\mathrm{NaR}$ cells and suppresses their proliferation (Figure 9).
Therefore, a loss of Trpv5/6 expression or function results in increased IGF signaling and elevated $\mathrm{NaR}$ cell proliferation under normal $\left[\mathrm{Ca}^{2+}\right]$ environments. Under low $\left[\mathrm{Ca}^{2+}\right]$, the altered Trpv5/6 activity activates IGF signaling in NaR cells and stimulates their proliferation (Figure 9). Blockage or inhibition of Trpv5/6 channel activity abolishes low $\left[\mathrm{Ca}^{2+}\right]$-induced activation of IGF signaling and NaR cell proliferation. The low $\left[\mathrm{Ca}^{2+}\right]-$ induced and Trpv5/6 activity-dependent activation of IGF signaling is likely mediated through membrane depolarization. A similar mechanism was observed in human colon epithelial cells. This model (Figure 9) provides a mechanistic explanation for the abnormal epithelial growth associated with $\mathrm{Ca}^{2+}$ deficiency. This model is in agreement with recent clinical studies reporting that PI3K and pAkt are highly expressed in colon cancer tissues. ${ }^{31}$

IGF ligands and IGF1Rs are expressed in most, if not all, tissues in mammals and in zebrafish. ${ }^{32,33}$ How is the ubiquitous IGF signaling system activated exclusively in $\mathrm{NaR}$ cells under low $\left[\mathrm{Ca}^{2+}\right.$ ] environments? Recent studies suggest that the net biological activities of the IGF signaling system are not only determined by the levels of IGF ligands and receptors but also modulated by various IGFBPs. ${ }^{15}$ Studies in mammalian systems have shown that IGFBP5 has several modes of action. In circulation, it is present in a tertiary complex containing IGFBP5, an IGF ligand, and the acidlabile subunit. ${ }^{34}$ This tertiary complex controls the efflux of IGFs from the vascular space and prolongs the half-lives of IGFs. IGFBP5 is also expressed in many fetal, neonatal, and adult tissues and local IGFBP5 can modulate IGF activities in an autocrine/paracrine manner ${ }^{15}$ or can have ligand-independent action..$^{35,36}$ In differentiating murine myoblasts, for example, IGFBP5 is located on the cell surface, and its expression is induced in the early stages during myogenesis. ${ }^{37}$ The cell surface-associated IGFBP5 binds to IGF-2 and brings IGF-2 into close proximity of the IGF1R, thereby enhancing IGF1R-mediated PI3K-Akt signaling activity. ${ }^{37}$ In NaR cells, locally expressed Igfbp5a likely acts in a similar fashion to facilitate the IGF ligand-receptor interaction. While our results support a positive role of local Igfbp5a in the low $\left[\mathrm{Ca}^{2+}\right]$-induced activation of IGF signaling in NaR cells, we do not think that Igfbp5a functions as the actual $\left[\mathrm{Ca}^{2+}\right]$ sensor. The reason for this is that the expression level of igfbp5a per $\mathrm{NaR}$ cell is not regulated by $\left[\mathrm{Ca}^{2+}\right]$, and that Igfbp5a does not contain any $\mathrm{Ca}^{2+}$-sensing EF-hand motifs. Other mechanisms must exist to sense the change in water $\left[\mathrm{Ca}^{2+}\right]$ and trigger the activation of IGF signaling in NaR cells.

In this study, we provide genetic and pharmacological evidence suggesting that Trpv5/6 has a critical role in regulating IGF signaling in NaR cells. First, mus mutant larvae, which have a loss-of-function mutation in the trpv5/6 gene, ${ }^{8}$ showed a dramatic increase in pAkt levels and elevated $\mathrm{NaR}$ cell proliferation rates under normal $\left[\mathrm{Ca}^{2+}\right]$. The elevated Akt signaling and $\mathrm{NaR}$ cell proliferation in the mus mutant larvae is IGF1R-dependent. Likewise, targeted knockdown of Trpv5/6 increased pAkt levels and NaR cell number under normal $\left[\mathrm{Ca}^{2+}\right]$. Blocking/inhibiting Trpv5/6 activity using four TRPV5/6 inhibitors/blockers all resulted in elevated pAkt signal in NaR cells under normal $\left.\mathrm{Ca}^{2+}\right]$ conditions. These data suggest that Trpv5/6 represses IGF signaling and suppresses $\mathrm{NaR}$ cell proliferation under normal 
a

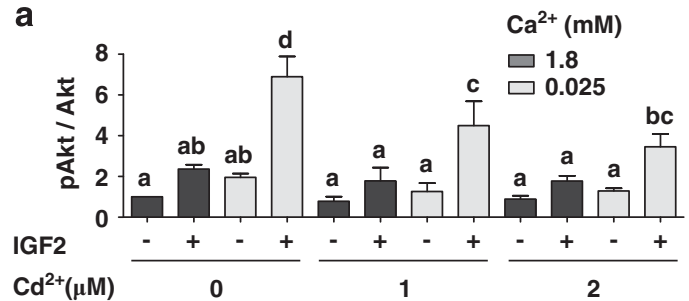

C

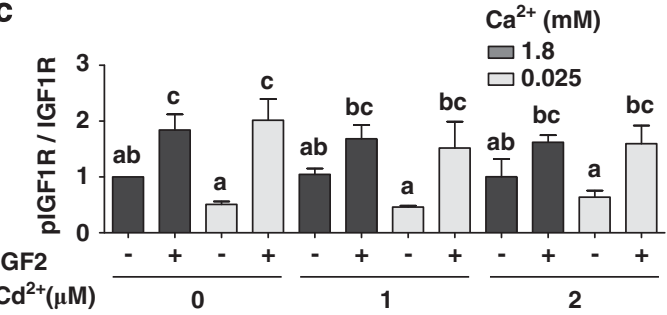

e

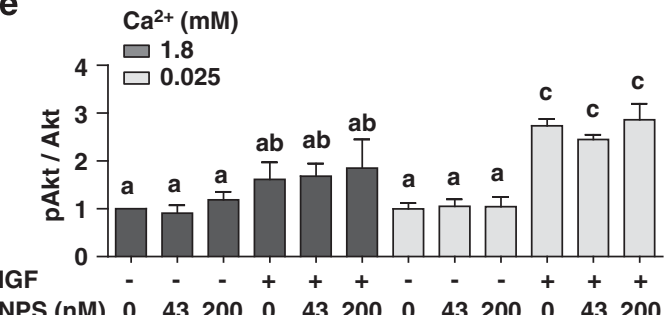

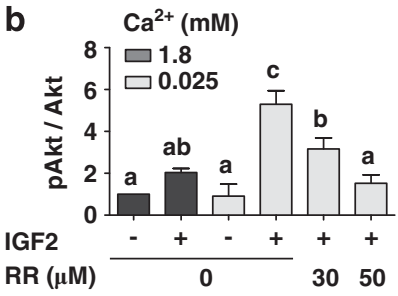

d

d $\quad \mathrm{Ca}^{2+}(\mathrm{mM})$

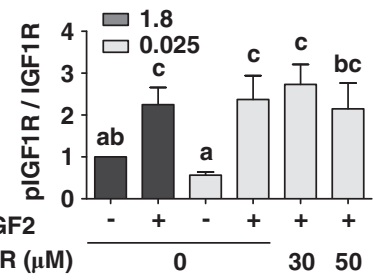

f $\quad \mathrm{n}=24212134 \quad 37212129$

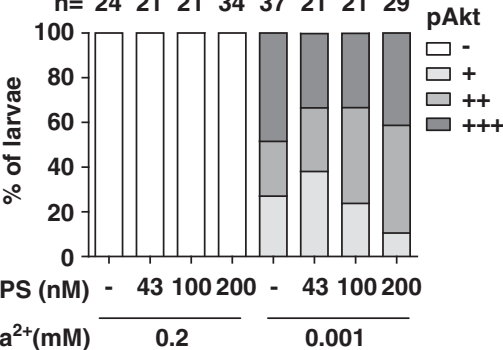

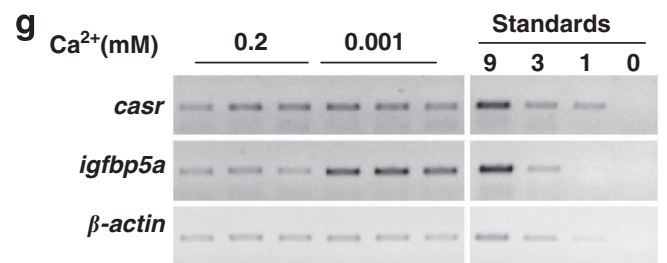

Figure 8 The low extracellular $\left[\mathrm{Ca}^{2+}\right.$ ]-induced amplification in IGF signaling requires TRPV6 but not CaSR. $(\mathbf{a}$ and $\mathbf{b})$ Effect of cadmium $\left(\mathrm{Cd}^{2+}\right)(\mathbf{a})$ and ruthenium red (RR) (b) on IGF-induced Akt signaling. Confluent Caco-2 cells were incubated in serum-free medium containing the indicated $\left[\mathrm{Ca}^{2+}\right]$ overnight together with the indicated inhibitors at the concentrations shown. IGF-2 $(200 \mathrm{ng} / \mathrm{ml})$ was added and cells were lysed $10 \mathrm{~min}$ later. The levels of pAkt and total Akt were analyzed and presented as described above. (c and d) Effect of $\mathrm{Cd}^{2+}$ (c) and RR (d) on IGF-induced pIGF1R. The experiments were the same as Figures 7a-b. The pIGF1R and total IGF1R levels were analyzed and presented as described above. (e) Effect of the CaSR inhibitor, NPS 2143, on IGF-induced Akt signaling in Caco-2 cells. The experiments were the same as Figures $7 \mathrm{a}$ and $\mathrm{b}$. The levels of pAkt and total Akt were analyzed and presented as described above. (f) Effect of NPS 2143 on low [ $\mathrm{Ca}^{2+}$ ]-induced Akt signaling in zebrafish larvae. Zebrafish larvae (72 hpf) were transferred to $0.2 \mathrm{mM}$ or $0.001 \mathrm{mM}\left[\mathrm{Ca}^{2+}\right]$ water containing the indicated concentrations of NPS 2143 . After $8 \mathrm{~h}$, they were stained for pAkt and scored. The total number of larvae analyzed from three independent experiments is shown on the top of each column. (g) Expression of casr mRNA in zebrafish larvae acclimated in normal and low $\left[\mathrm{Ca}^{2+}\right]$. Total RNA was isolated from $120 \mathrm{hpf}$ larvae. The casr mRNA levels were measured by RT-PCR and shown

$\left[\mathrm{Ca}^{2+}\right]$. Unexpectedly and most intriguingly, blocking/inhibiting TRPV5/6 activity abolishes low $\left[\mathrm{Ca}^{2+}\right]$-induced Akt signaling and NaR cell proliferation. This effect is unlikely caused by any non-specific toxicity associated with chemical inhibitors because (a) all four different TRVP5/6 inhibitors had similar effects, while blocking the L-type $\mathrm{Ca}^{2+}$ channel and the potassium channel had no such effect; (b) their inhibitory effects were absent in the mus mutant larvae under normal $\left[\mathrm{Ca}^{2+}\right]$; (c) their inhibitory effects were reversed by artificial membrane depolarization. Based on these findings, we postulate that Trpv5/6 has dual roles in regulating IGF signaling in NaR cells. While Trpv5/6 represses IGF signaling in NaR cells under normal $\left[\mathrm{Ca}^{2+}\right.$ ], the same Trpv5/6 activates IGF signaling in $\mathrm{NaR}$ cells under low $\left[\mathrm{Ca}^{2+}\right]$.
How does the same Trpv5/6 exert these dual roles in regulating IGF signaling under normal and low $\left[\mathrm{Ca}^{2+}\right]$ conditions and how are changes in $\left[\mathrm{Ca}^{2+}\right]$ sensed and signaled in these cells? We considered and explored several possibilities. Changes in extracellular $\left[\mathrm{Ca}^{2+}\right]$ are known to be sensed by the CaSR. ${ }^{27}$ Activation of CaSR has been shown to increase mammalian TRPV5 activity. ${ }^{38}$ This possibility was not supported by our data. Addition of a CaSR antagonist did not affect basal or $\mathrm{Ca}^{2+}$ deficiency-induced Akt signaling in human Caco-2 cells or in NaR cells. We also explored the possible involvement of intracellular $\mathrm{Ca}^{2+} / \mathrm{CaM}$ signaling. In zebrafish $\mathrm{NaR}$ cells, however, $\mathrm{CaM}$ antagonists and $\mathrm{Ca}^{2+}$ chelating agent did not affect Akt activity. A recent study reported that IGF-1 is secreted by $\mathrm{Ca}^{2+}$-triggered exocytosis 

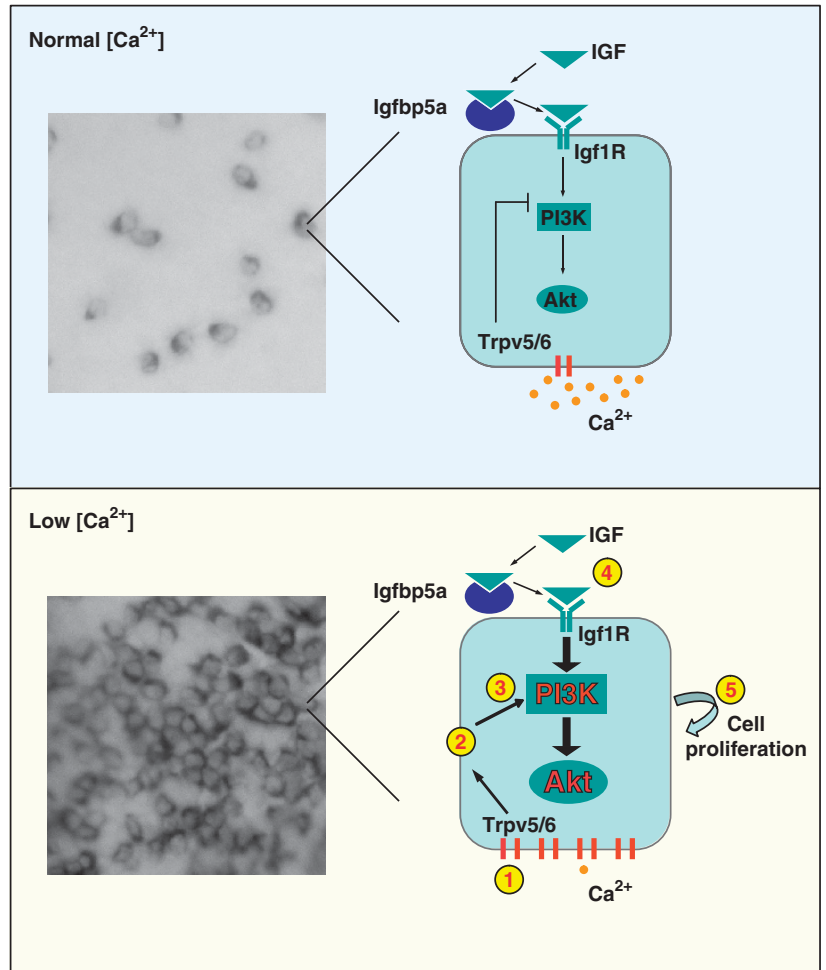

Figure 9 A proposed model on how Trpv5/6 regulates IGF signaling and epithelial growth under normal and $\mathrm{Ca}^{2+}$-deficient conditions. Upper panel: under normal $\left[\mathrm{Ca}^{2+}\right]$, the activity of IGF1R-PI3K-Akt signaling in NaR cells is under the negative regulation of Trpv5/6 and cell proliferation is kept at low levels. As a result, there are a limited number of $\mathrm{NaR}$ cells on the larval yolk sac skin. Lower panel: under low $\left[\mathrm{Ca}^{2+}\right]$ environments, the number and density of $\mathrm{NaR}$ cells increase dramatically due to elevated proliferation of pre-existing $\mathrm{NaR}$ cells. Low $\left[\mathrm{Ca}^{2+}\right]$ results in changes in Trpv5/6 activity (1). This leads to membrane depolarization (2), which in turn leads to the amplification of IGF signaling at the levels of PI3K and Akt (3). Local Igfbp5a facilitates the IGF ligand and receptor binding (4). The activation of IGF1R-PI3K-Akt signaling stimulates NaR cells to re-enter the cell cycle (5), leading to the increased NaR cell number and density

in mammalian olfactory bulb neurons. ${ }^{39}$ Whether low $\left[\mathrm{Ca}^{2+}\right]$ treatment may alter the exocytosis of IGF ligands in zebrafish larvae or in colon cells is not known at present. However, if such a mechanism is at work, one would expect to see increased pIGF1R levels under low $\left[\mathrm{Ca}^{2+}\right]$. Our experiments in Caco-2 cells showed that the low $\left[\mathrm{Ca}^{2+}\right]$-induced amplification of signaling response to IGF-2 occurs at the levels of p85, PDK1, and pAkt, while no such amplification was observed in the levels of pIGF1R. Another possible mechanism is the anomalous mole faction behavior of the TRPV5 and TRPV6 channels. The current amplitudes of these channels decrease when extracellular $\left[\mathrm{Ca}^{2+}\right]$ is lowered from 10 to $0.1 \mathrm{mM}$, but are elevated when extracellular $\left[\mathrm{Ca}^{2+}\right]$ is further reduced from 0.1 to $0.001 \mathrm{mM},{ }^{25,40}$ suggesting that the channel activity can be directly regulated by environmental $\left[\mathrm{Ca}^{2+}\right]$. Our available data support this scenario. The concentration of extracellular $\mathrm{Ca}^{2+}$ to induce Akt phosphorylation $(0.02$ and $0.001 \mathrm{mM})$ correlates well with that to increase TRPV $5 / 6$ current amplitude $(<0.1 \mathrm{mM})$.

Although it was initially thought that TRPV5/6 are constitutively open based on experiments showing elevated intracelluar free $\left[\mathrm{Ca}^{2+}\right]$ in $\mathrm{Ca}^{2+}$ indicator dye fura-2-loaded
TRPV5-expressing HEK cells, ${ }^{24}$ it was later shown that this is likely due to an effect of fura-2 in buffering intracelluar $\left[\mathrm{Ca}^{2+}\right]$, because patch-clamp recording indicated no spontaneous channel activity. ${ }^{41}$ It is now understood that TRPV $5 / 6$ channels are negatively regulated by extracellular $\left[\mathrm{Ca}^{2+}\right]$, and that lowering extracellular $\left[\mathrm{Ca}^{2+}\right]$ can increase the channel conductance to monovalent cations such as $\mathrm{Na}^{+}{ }^{24,40,42}$ Membrane depolarization has been shown to activate the PI3K-Akt signaling in neuronal cells. ${ }^{43,44}$ Link et al. ${ }^{45}$ have reported that TRPV2 activity induces membrane depolarization during immune complex-induced phagocytosis. We hypothesized that the influx of $\mathrm{Na}^{+}$through Trvp5/6 under the low $\left[\mathrm{Ca}^{2+}\right]$ condition may lead to membrane depolarization, which in turn increases IGF signaling in these cells. In this study, we tested this hypothesis by provoking artificial membrane polarization. At present, direct measurement of membrane potential in $\mathrm{NaR}$ cells is difficult. These cells are buried underneath the pavement cells, which are very tough to penetrate. One has to peel off the skin and patch from the basal-lateral side, which would destroy the skin integrity. Future efforts are needed to develop new techniques to monitor membrane potential in $\mathrm{NaR}$ cells directly or indirectly in order to further test this hypothesis.

In conclusion, we have unraveled a novel and evolutionarily conserved signaling mechanism linking the $\mathrm{Ca}^{2+}$-selective cation channel, TRPV5/6, to the IGF-induced PI3K-PDK1-Akt signaling pathway. This signaling module is activated under $\mathrm{Ca}^{2+}$-deficient conditions in epithelial cells exclusively. We provide direct evidence that this signaling mechanism has a pivotal role in $\mathrm{Ca}^{2+}$ deficiency-induced abnormal epithelial growth. We also show that a similar signaling mechanism is functional in human colon cancer cells. It has been documented for half a century that low $\left[\mathrm{Ca}^{2+}\right]$ induces colon cell proliferation in vitro and in vivo. ${ }^{46,47}$ Although several recent studies have shown that TRPV6 overexpression is often associated with increased cell proliferation in colon, breast, and prostate cancers, ${ }^{48-50}$ it is not clear how an increase in TRPV5/6 levels leads to elevated proliferation. The $\mathrm{Ca}^{2+}$ deficiency-induced and Trpv5/6-dependent IGF signaling unraveled by this study provides a possible mechanistic explanation for the elevated epithelial cell proliferation in $\mathrm{Ca}^{2+}$ deficiency. Our findings also uncover a novel role of IGF signaling in regulating epithelial growth in zebrafish in response to low $\left[\mathrm{Ca}^{2+}\right]$. Although the role of IGF signaling in regulating normal growth and development is well established, it has only recently become evident that the IGF signaling pathway is often co-opted in various adaptive responses. For example, IGF signaling is increased and has a role in the exercise-induced skeletal muscle hypertrophy in mammals, ${ }^{51}$ in fin regeneration upon amputation in zebrafish, ${ }^{52}$ and in catch-up growth during re-oxygenation in zebrafish. ${ }^{53}$ The results of the present study, along with those mentioned above, suggest that co-option of the ubiquitous IGF signaling pathway in regulating plastic changes of specific tissues in response to environmental factors may be a common theme.

\section{Materials and Methods}

Chemicals and reagents. All chemicals and reagents were purchased from Fisher Scientific (Pittsburgh, PA, USA) unless stated otherwise. Oligonucleotide 
primers, cell culture media, and supplements were purchased from Invitrogen (Carlsbad, CA, USA). BMS-754807 and NVP-AEW541 were obtained from JiHe Pharmaceutica (Beijing, China) and Novartis (Basel, Switzerland). Wortmannin, LY294002, U0126, and PD98059 were purchased from Cell Signaling Technology (Danvers, MA, USA), MK2206 and Akti-1/2 from ChemieTek (Indianapolis, IN, USA) and EMD Chemicals (Billerica, MA, USA), SU5402 and NPS-2143 from Tocris Bioscience (Bristol, UK), and AG1478 from Cayman Chemical (Ann Arbor, MI, USA). EGTA, cadmium chloride, ruthenium red, lanthanum chloride, and gadolinium chloride were purchased from Sigma-Aldrich (St Louis, MO, USA). Antibodies against phospho-IGF1R (Tyr 1161) and IGF1R $\beta$ (C-20) were from Santa Cruz Biotechnology (Santa Cruz, CA, USA). Phospho-Akt (Ser 473), total Akt, phosphoErk (Thr202/Tyr204), total Erk, and total PDK1 antibodies were from Cell Signaling Technology. Antibodies against the p85 subunit of PI3 Kinase and phosphotyrosine (4G10) were bought from Millipore (Billerica, MA, USA). MOs were purchased from GeneTools (Philomath, OR, USA).

Experimental animals. Wild-type zebrafish (Danio rerio) were maintained on a $14 \mathrm{~h}$ light $/ 10 \mathrm{~h}$ dark cycle at $28^{\circ} \mathrm{C}$ and fed twice daily. Fertilized eggs were kept at $28.5^{\circ} \mathrm{C}$ and staged according to the standard method. ${ }^{54} \mathrm{~N}$-phenylthiourea was added $(0.003 \% \mathrm{w} / \mathrm{v})$ to inhibit pigmentation. Artificial freshwater with different $\mathrm{Ca}^{2+}$ and other ion concentrations was prepared using double deionized water generated by Milli-Q Academic System (Millipore). The nominal ion concentration and osmolarity are shown in Supplementary Table S1. All experiments were conducted in accordance with the guidelines approved by the University Committee on the Use and Care of Animals, University of Michigan. Zebrafish trpv5/6 mutant embryos were generated by crossing two identified adult fish heterozygous for the mus ${ }^{\mathrm{t} 25927}$ mutation. ${ }^{8}$ Stained fish were genotyped following the published KASPar SNP genotyping method. ${ }^{8}$

Whole-mount in situ hybridization. Single-color in situ hybridization using digoxigenin (DIG)-labeled antisense riboprobes was carried out as reported previously. ${ }^{14}$ Images were captured with a stereomicroscope (Leica MZ16F, Leica, Wetzlar, Germany) equipped with a QImaging QICAM camera (QImaging, Surrey, BC, Canada), or a compound microscope (Nikon Eclipse E600, Nikon, Tokyo, Japan) equipped with a Photometric CoolSNAP EZ camera (Photometrics, Tucson, AZ, USA). For double-label in situ hybridization, igfbp5a, ${ }^{14}$ trpv5/6, ${ }^{11}$ and

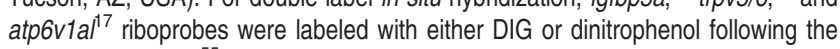
published protocol. ${ }^{55}$ Fluorescent images were acquired using a Leica TCS SP5 confocal microscope with the Leica LAS AF software.

RT-PCR and quantitative real-time PCR (qRT-PCR). Total RNA was isolated using TRIzol reagent (Invitrogen). $1 \mu \mathrm{g}$ RNA was reverse-transcribed to CDNA using M-MLV reverse transcriptase (Invitrogen). RT-PCR was performed using Taq DNA polymerase (New England Biolabs, Ipswich, MA, USA). qRT-PCR was carried out using iQ SYBR Green Supermix (Bio-Rad, Hercules, CA, USA) with an iCycler iQ Multicolor real-time PCR detection system (Bio-Rad). The efficiency and specificity of the $\mathrm{QPCR}$ were verified by standard curve and denaturing curve analyses. The expression level of a particular gene transcript was calculated based on the standard curve and normalized by the $\beta$-actin levels. Primers used are shown in Supplementary Table S2.

BrdU labeling. BrdU-labeling experiments were performed by incubating zebrafish larvae in artificial freshwater containing $10 \mathrm{mM}$ BrdU (Sigma-Aldrich). Cells incorporating BrdU were detected by immunostaining using a mouse antiBrdU antibody (Sigma-Aldrich) at 1:200 followed by Nickel-diaminobenzidine staining or immunofluorescence. In some experiments, fish larvae were subjected to in situ hybridization using DIG-labeled riboprobe followed by BrdU staining.

Immunostaining. Zebrafish larvae were fixed in $4 \%$ paraformaldehyde, permeabilized in methanol, and subjected to blocking solution containing $5 \%$ normal donkey serum. Samples were then incubated with primary antibody overnight at $4{ }^{\circ} \mathrm{C}$, washed, and then incubated with an anti-rabbit HRP antibody (Jackson ImmunoResearch, West Grove, PA, USA) followed by nickeldiaminobenzidine staining or immunofluorescence. For in situ hybridization and immunofluorescence co-staining, samples were subjected to in situ hybridization (omit proteinase $\mathrm{K}$ treatment) and then to immunostaining.

Western blot and ligand blot. The construction of the IGFBP::GFP and IGFBP::myc expression vectors were described previously. ${ }^{14}$ Human IGFBP5 and its ligand binding domain mutant (K68N/P69Q/L70Q/L73Q/L74Q) were used as positive and negative controls. These constructs were transiently transfected into HEK 293 cells using Lipofectamine 2000 (Invitrogen). One day after the transfection, cells were switched to serum-free medium containing $200 \mu \mathrm{g} / \mathrm{ml}$ heparin to prevent possible degradation. Conditioned media were collected after $48 \mathrm{~h}$, and analyzed by western blot using an anti-GFP antibody (Torrey Pines Biolabs, Secaucus, NJ, USA) or an anti-myc antibody (Santa Cruz Biotechnology). They were also subjected to ligand blot using DIG-labeled human IGF-1 and IGF-2 as reported previously. ${ }^{14}$

Co-immunoprecipitation (IP). Immunoprecipitation was performed using the $4 \mathrm{G} 10$ or anti-p85 antibodies following previously published protocol. ${ }^{41}$ The immunoprecipitated complex was analyzed by western blot using anti-p85, anti-PDK1, and 4G10 antibodies as described above. The ratios of phosphorylated to total protein were calculated after the images had been analyzed by densitometry using a Fluor-S Imager (Bio-Rad) and ImageJ software.

MO injection and verification. MOs were injected into 1-2-cell stage embryos. Two translation-blocking MOs were used to knockdown lgfbp5a (M01: 5'-CAAACTTAGCAGCATCGTCCTACTG-3' targeting nucleotides -10 to 15; MO2: 5'-TTTGTATCGTTTAAGGTTCCCGAGT-3' targeting nucleotides -78 to -54$)$ and injected at $(4 \mathrm{ng}+4 \mathrm{ng}) /$ embryo. A previously validated Trpv5/6 $\mathrm{MO}^{22}$ was injected at $4 \mathrm{ng} / \mathrm{embryo}$. A standard control MO (5'-CCTCTTACCT CAGTTACAATTTATA-3') was injected at the same concentration as the test group. To verify the efficiency and specificity of these MOs for blocking the translation initiation complex on igfbp5a, we constructed a GFP reporter containing partial $5^{\prime}$ UTR and coding sequence of igfbp5a or igfbp5b. DNA fragments containing $81 \mathrm{bp}$ of $5^{\prime} U T R$ and $99 \mathrm{bp}$ of coding sequence of igfbp5a, or $91 \mathrm{bp}$ of $5^{\prime} U T R$ and $99 \mathrm{bp}$ of coding sequence of igfbp5b were PCR-amplified and cloned into the pCS2-EGFP ${ }^{14}$ at BamHI/Clal sites. Primers used are shown in Supplementary Table S2. These reporter plasmids $(250 \mathrm{pg})$ were injected into 1-2cell stage embryos alone or together with lgfbp5a targeting MOs or the standard control MO.

Cell culture and flowcytometry analysis. Human colorectal adenocarcinoma (Caco-2) cells and embryonic kidney (HEK293) cells were cultured in DMEM supplemented with $10 \%$ FBS, penicillin, and streptomycin in a humidifiedair atmosphere incubator containing $5 \% \mathrm{CO}_{2}$ at $37^{\circ} \mathrm{C}$. To examine the effect of $\left[\mathrm{Ca}^{2+}\right]$, culture media with different $\left[\mathrm{Ca}^{2+}\right]$ were prepared by adding $\mathrm{CaCl}_{2}$ to DMEM without $\mathrm{Ca}^{2+}$ at the desired concentration. After washing three times with these media, Caco-2 cells were incubated overnight before IGF treatment. Cell cycle analysis was carried out using a FACS Calibur flow cytometer (BD Biosciences, Franklin Lakes, NJ, USA) as previously described. ${ }^{21}$

Statistics. Differences among experimental groups were analyzed by one-way ANOVA followed by Tukey's multiple comparison test using GraphPad Prism 5 (GraphPad Software, La Jolla, CA, USA). Correlation analysis was carried out by fitting the data to the equation $Y=X$ to calculate $r^{2}$ using GraphPad Prism 5 (GraphPad Software). Data shown are mean \pm standard deviation (S.D.). Significance was accepted at $P<0.05$ or greater.

\section{Conflict of Interest}

The authors declare no conflict of interest.

Acknowledgements. We are grateful to Dr. Stefan Schulte-Merker, Hubrecht Institute, the Netherlands for providing the mus mutant fish line, Dr. Pung-Pung Hwang, Institute of Cellular and Organismal Biology, Academia Sinica in Taiwan, for sharing the double-label in situ hybridization protocol. We thank Dr. Haoxing Xu, University of Michigan, for reading and commenting on an earlier version of this manuscript. This work was supported by NIH Grant 1R21AG040604-01A1 and NSF Grant IOS-1051034 to CD.

\section{Author contribution}

$C D$ and WD designed the research; WD, YB, LH, XZ, JL, and J.K. performed research; $C D, W D, Y B$, and $X Z$ analyzed the data; and $C D$ and $W D$ wrote the paper. 
1. Kampman E, Slattery ML, Caan B, Potter JD. Calcium, vitamin D, sunshine exposure dairy products and colon cancer risk (United States). Cancer Causes Control 2000; 11: 459-466.

2. McCullough ML, Robertson AS, Rodriguez C, Jacobs EJ, Chao A, Carolyn J et al. Calcium, vitamin D, dairy products, and risk of colorectal cancer in the Cancer Prevention Study I Nutrition Cohort (United States). Cancer Causes Control 2003; 14: 1-12.

3. Wakai K, Hirose K, Matsuo K, Ito H, Kuriki K, Suzuki T et al. Dietary risk factors for colon and rectal cancers: a comparative case-control study. J Epidemiol 2006; 16: 125-135.

4. Lamprecht SA, Lipkin M. Chemoprevention of colon cancer by calcium, vitamin D and folate: molecular mechanisms. Nat Rev Cancer 2003; 3: 601-614.

5. Peterlik M, Cross HS. Vitamin D and calcium deficits predispose for multiple chronic diseases. Eur J Clin Invest 2005; 35: 290-304.

6. Hwang PP. Ion uptake and acid secretion in zebrafish (Danio rerio). J Exp Biol 2009; 212 1745-1752.

7. Flik G, Verbost PM, Wendelaar Bongar SE. Calcium transport process in fishes. In: Wood CM, Shuttleworth TJ (eds). Cellular and molecular approaches to fish ionic regulation. Academic San Diego, CA, USA, 1995, pp 317-342.

8. Vanoevelen J, Janssens A, Huitema LF, Hammond CL, Metz JR, Flik G et al. Trpv5/6 is vital for epithelial calcium uptake and bone formation. FASEB J 2011; 25: 3197-3207.

9. Clapham DE. TRP channels as cellular sensors. Nature 2003; 426: 517-524.

10. Hoenderop JG, Nilius B, Bindels RJ. Calcium absorption across epithelia. Physiol Rev 2005; 85: 373-422.

11. Pan TC, Liao BK, Huang CJ, Lin LY, Hwang PP. Epithelial $\mathrm{Ca}(2+)$ channel expression and $\mathrm{Ca}(2+)$ uptake in developing zebrafish. Am J Physiol Regul Integr Comp Physio 2005; 289: R1202-R1211.

12. Perry SF, Wood CM. Kinetics of branchial calcium uptake in the rainbow trout: effects of acclimation to various external calcium levels. J Exp Biol 1985; 116: 411-433.

13. McCormick SD, Hasegawa S, Hirano T. Calcium uptake in the skin of a freshwater teleost. Proc Natl Acad Sci USA 1992; 89: 3635-3638.

14. Dai W, Kamei H, Zhao Y, Ding J, Du Z, Duan C. Duplicated zebrafish insulin-like growth factor binding protein-5 genes with split functional domains: evidence for evolutionarily conserved IGF binding, nuclear localization, and transactivation activity. FASEB J 2010; 24: $2020-2029$

15. Duan $\mathrm{C}, \mathrm{Xu} \mathrm{Q}$. Roles of insulin-like growth factor (IGF) binding proteins in regulating IGF actions. Gen Comp Endocrinol 2005; 142: 44-52.

16. Pozios KC, Ding J, Degger B, Upton Z, Duan C. IGFs stimulate zebrafish cell proliferation by activating MAP kinase and PI3-kinase-signaling pathways. Am J Physiol Regul Integr Comp Physiol 2001; 280: R1230-R1239.

17. Lin LY, Horng JL, Kunkel JG, Hwang PP. Proton pump-rich cell secretes acid in skin of zebrafish larvae. Am J Physiol Cell Physiol 2006; 290: C371-C378.

18. Wang YF, Tseng YC, Yan JJ, Hiroi J, Hwang PP. Role of SLC12A10.2, a Na-Cl cotransporter-like protein, in a $\mathrm{Cl}$ uptake mechanism in zebrafish (Danio rerio). Am J Physiol Regul Integr Comp Physiol 2009; 296: R1650-R1660.

19. Carboni JM, Wittman M, Yang Z, Lee F, Greer A, Hurlburt W et al. BMS-754807, a small molecule inhibitor of insulin-like growth factor-1R/IR. Mol Cancer Ther2009; 8: 3341-3349.

20. Garcia-Echeverria C, Marti A, Meyer T, Mestan J, Zimmermann J, Gao J et al. In vivo antitumor activity of NVP-AEW541-A novel, potent, and selective inhibitor of the IGF-IR kinase. Cancer Cell 2004; 5: 231-239.

21. Schlueter PJ, Peng G, Westerfield M, Duan C. Insulin-like growth factor signaling regulates zebrafish embryonic growth and development by promoting cell survival and cell cycle progression. Cell Death Differ 2007; 14: 1095-1105.

22. Tseng DY, Chou MY, Tseng YC, Hsiao CD, Huang CJ, Kaneko T et al. Effects of stanniocalcin 1 on calcium uptake in zebrafish (Danio rerio) embryo. Am J Physiol Regul Integr Comp Physiol 2009; 296: R549-R557.

23. Deb TB, Coticchia CM, Dickson RB. Calmodulin-mediated activation of Akt regulates survival of c-Myc-overexpressing mouse mammary carcinoma cells. J Biol Chem 2004; 279: 38903-38911.

24. Vennekens R, Hoenderop JG, Prenen J, Stuiver M, Willems PH, Droogmans G et al. Permeation and gating properties of the novel epithelial $\mathrm{Ca}(2+)$ channel. J Biol Chem 2000; 275: 3963-3969

25. Yue L, Peng JB, Hediger MA, Clapham DE. CaT1 manifests the pore properties of the calcium-release-activated calcium channel. Nature 2001; 410: 705-709.

26. Wood RJ, Tchack L, Taparia S. 1,25-Dihydroxyvitamin D3 increases the expression of the CaT1 epithelial calcium channel in the Caco-2 human intestinal cell line. BMC Physiol 2001; 1: 11.

27. Brennan SC, Thiem U, Roth S, Aggarwal A, Fetahu ISh, Tennakoon S et al. Calcium sensing receptor signalling in physiology and cancer. Biochim Biophys Acta 2013; 2013: 1732-1744

28. Whitfield JF. The calcium-sensing receptor-a driver of colon cell differentiation. Curr Pharm Biotechnol 2009; 10: 311-316.
29. Nemeth EF, Delmar EG, Heaton WL, Miller MA, Lambert LD, Conklin RL et al. Calcilytic compounds: potent and selective $\mathrm{Ca} 2+$ receptor antagonists that stimulate secretion of parathyroid hormone. J Pharmacol Exp Ther 2001; 299: 323-331.

30. Varani J. Calcium, calcium-sensing receptor and growth control in the colonic mucosa. Histol Histopathol 2011; 26: 769-779.

31. Zhang Y, Liu X, Zhang J, Li L, Liu C. The expression and clinical significance of PI3K pAkt and VEGF in colon cancer. Oncol Lett 2012; 4: 763-766.

32. Maures T, Chan SJ, Xu B, Sun H, Ding J, Duan C. Structural, biochemical, and expression analysis of two distinct insulin-like growth factor I receptors and their ligands in zebrafish. Endocrinology 2002; 143: 1858-1871.

33. Zou S, Kamei H, Modi Z, Duan C. Zebrafish IGF genes: gene duplication, conservation and divergence, and novel roles in midline and notochord development. PLoS One 2009; 4 e7026.

34. Twigg SM, Baxter RC. Insulin-like growth factor (IGF)-binding protein 5 forms an alternative ternary complex with IGFs and the acid-labile subunit. J Biol Chem 1998; 273: 6074-6079.

35. Miyakoshi N, Richman C, Kasukawa Y, Linkhart TA, Baylink DJ, Mohan S. Evidence that IGF-binding protein-5 functions as a growth factor. J Clin Invest 2001; 107: 73-81.

36. Hsieh T, Gordon RE, Clemmons DR, Busby WH Jr., Duan C. Regulation of vascular smooth muscle cell responses to insulin-like growth factor (IGF)-I by local IGF-binding proteins. J Biol Chem 2003; 278: 42886-42892.

37. Ren $\mathrm{H}$, Yin P, Duan C. IGFBP-5 regulates muscle cell differentiation by binding to IGF-II and switching on the IGF-II auto-regulation loop. J Cell Biol 2008; 182: 979-991.

38. Topala CN, Schoeber JP, Searchfield LE, Riccardi D, Hoenderop JG, Bindels RJ. Activation of the $\mathrm{Ca} 2+$-sensing receptor stimulates the activity of the epithelial Ca2 + channel TRPV5. Cell Calcium 2009; 45: 331-339.

39. Cao P, Maximov A, Sudhof TC. Activity-dependent IGF-1 exocytosis is controlled by the $\mathrm{Ca}(2+)$-sensor synaptotagmin-10. Cell 2011; 145: 300-311.

40. Vennekens R, Prenen J, Hoenderop JG, Bindels RJ, Droogmans G, Nilius B. Pore properties and ionic block of the rabbit epithelial calcium channel expressed in HEK 293 cells. J Physiol 2001; 530: 183-191.

41. Bodding M, Flockerzi V. Ca2 + dependence of the Ca2 +-selective TRPV6 channel. J Biol Chem 2004; 279: 36546-36552.

42. Nilius B, Vennekens R, Prenen J, Hoenderop JG, Bindels RJ, Droogmans G. Whole-cell and single channel monovalent cation currents through the novel rabbit epithelial $\mathrm{Ca} 2$ + channel ECaC. J Physiol 2000; 527(Pt 2): 239-248.

43. Miller TM, Tansey MG, Johnson EM Jr, Creedon DJ. Inhibition of phosphatidylinositol 3-kinase activity blocks depolarization- and insulin-like growth factor I-mediated survival of cerebellar granule cells. J Biol Chem 1997; 272: 9847-9853.

44. Vaillant AR, Mazzoni I, Tudan C, Boudreau M, Kaplan DR, Miller FD. Depolarization and neurotrophins converge on the phosphatidylinositol 3-kinase-Akt pathway to synergistically regulate neuronal survival. J Cell Biol 1999; 146: 955-966.

45. Link TM, Park U, Vonakis BM, Raben DM, Soloski MJ, Caterina MJ. TRPV2 has a pivotal role in macrophage particle binding and phagocytosis. Nat Immunol 2010; 11: 232-239.

46. Kallay $\mathrm{E}$, Kifor O, Chattopadhyay N, Brown EM, Bischof MG, Peterlik M et al. Calcium-dependent c-myc proto-oncogene expression and proliferation of $\mathrm{Caco}-2$ cells: a role for a luminal extracellular calcium-sensing receptor. Biochem Biophys Res Commun 1997; 232: 80-83.

47. Buset M, Lipkin M, Winawer S, Swaroop S, Friedman E. Inhibition of human colonic epithelial cell proliferation in vivo and in vitro by calcium. Cancer Res $1986 ; 46$ : 5426-5430.

48. Bolanz KA, Hediger MA, Landowski CP. The role of TRPV6 in breast carcinogenesis. Mol Cancer Ther 2008; 7: 271-279.

49. Zhuang L, Peng JB, Tou L, Takanaga $\mathrm{H}$, Adam RM, Hediger MA et al. Calcium-selective ion channel, CaT1, is apically localized in gastrointestinal tract epithelia and is aberrantly expressed in human malignancies. Lab Invest 2002; 82: 1755-1764.

50. Lehen'kyi V, Flourakis M, Skryma R, Prevarskaya N. TRPV6 channel controls prostate cancer cell proliferation via $\mathrm{Ca}(2+) /$ NFAT-dependent pathways. Oncogene 2007; 26: 7380-7385

51. Adams GR. Invited Review: Autocrine/paracrine IGF-I and skeletal muscle adaptation. J Appl Physiol 2002; 93: 1159-1167.

52. Chablais F, Jazwinska A. IGF signaling between blastema and wound epidermis is required for fin regeneration. Development 2010; 137: 871-879.

53. Kamei H, Ding Y, Kajimura S, Wells M, Chiang P, Duan C. Role of IGF signaling in catch-up growth and accelerated temporal development in zebrafish embryos in response to oxygen availability. Development 2011; 138: 777-786.

54. Kimmel CB, Ballard WW, Kimmel SR, Ullmann B, Schilling TF. Stages of embryonic development of the zebrafish. Dev Dyn 1995; 203: 253-310.

55. Hsiao CD, You MS, Guh YJ, Ma M, Jiang YJ, Hwang PP. A positive regulatory loop between foxi3a and foxi3b is essential for specification and differentiation of zebrafish epidermal ionocytes. PLoS One 2007; 2: e302. 